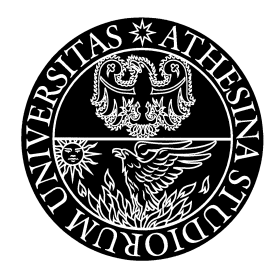

UNIVERSITA' DEGLI STUDI DI TRENTO - DIPARTIMENTO DI ECONOMIA

\title{
INTERREGIONAL INCOME REDISTRIBUTION AND CONVERGENCE IN A MODEL WITH PERFECT CAPITAL MOBILITY AND UNIONIZED LABOR MARKETS
}

Luigi Bonatti

Discussion Paper No. 2, 2002 
The Discussion Paper series provides a means for circulating preliminary research results by staff of or visitors to the Department. Its purpose is to stimulate discussion prior to the publication of papers.

Requests for copies of Discussion Papers and address changes should be sent to:

Prof. Andrea Leonardi

Dipartimento di Economia

Università degli Studi

Via Inama 5

38100 TRENTO ITALY 
INTERREGIONAL INCOME REDISTRIBUTION AND

CONVERGENCE IN A MODEL WITH PERFECT CAPITAL

MOBILITY AND UNIONIZED LABOR MARKETS

Luigi Bonatti *

Università di Trento

"Address: Luigi Bonatti - via Moscova 58 - 20121 Milano (ITALY); phone: 39+02+6599863; fax: 39+0461+882222; e-mail: LBONATTI@GELSO.UNITN.IT. 


\begin{abstract}
The model presents a general equilibrium dynamic model of an economy consisting of many regions. Capital is perfectly mobile and labor is immobile across regions. Wages are determined by local unions. There is training on the job and strategic complementarity between investment in physical capital by firms and investment in becoming "trainable" by workers. Structurally similar regional economies preserve forever their differences in per capita output and employment rate, if the workers' non-labor is equalized across regions by interregional income redistribution operated via central budget. Regional decentralization of income redistribution allows convergence in per capita output and employment rate.
\end{abstract}

KEY WORDS: Growth, on-the-job training, skilled labor, strategic complementarity, fiscal transfers.

JEL CLASSIFICATION NUMBERS: J24, J51, J64, O41, R11. 


\section{INTRODUCTION}

The value added of the general equilibrium dynamic model presented in this paper consists in combining unemployment theory and growth theory in order to improve understanding of the relevant mechanisms through which disparities in per capita output and employment rates may persist across regions. In particular, the focus is on the role that interregional fiscal transfers may play in the process of convergence in levels across regions. In this regard, the paper can contribute to clarify the long-term implications of those programs that redistribute income across regions or across countries of a union (or across states of a union) via central budgets. Therefore, the conclusions of the paper can be relevant for the debate on the merits of fiscal federalism and on the degrees of centralization of redistribution both at the national and at the supernational level.

The paper is strongly motivated by the recent experience of continental Europe. In the last two decades, indeed, differences in GDP per capita between European regions have appeared to be quite persistent (Neven and Gouyette, 1995; Fagerberg and Verspagen, 1996). Typically, regions with lower level of 
GDP per capita tend to be those having the higher rate of unemployment (Caniëls et al., 1997), and regions which had the lowest unemployment rates at the beginning of the 1980 s still tend to have the lowest rates at the end of the 1990s (European Commission, 1999). Moreover, particularly in Southern Europe -- where some of the regions with the highest unemployment rates are located -- unemployment is closely concentrated among young people and (especially in South Italy) among first-job seekers. However, in spite of longlasting (and rising) differentials in regional unemployment rates, interregional migration flows have declined and then remained very low in the last two decades: ${ }^{1}$ in contrast to the USA, where migration flows are important to accommodate region-specific shocks (see Blanchard and Katz, 1992), the adjustment pattern in countries like Italy and Germany seem to involve larger and more persistent changes in labor-market participation (see Obstfeld and Peri, 1998). ${ }^{2}$ As a result, it is often the case that depressed areas exhibit lower rates of labor force participation and have relatively large underground

\footnotetext{
${ }^{1}$ Since the mid 1970s labor flows across European regions have decreased rapidly, practically coming to a stop in the last decade. In contrast, gross capital flows have grown considerably during the same period.
} 
economies. Consistently with this picture, wages do not seem to be particularly sensitive to local labor market imbalances.

It is often argued that generous transfers and (relatively) uniform social benefits tend to disproportionally depress work incentives for residents in poorer areas (e. g. Bertola, 2001), raising their reservation wages, discouraging their labor-market participation and lowering their propensity to migrate. Many observers consider East Germany and Southern Italy (the two "Mezzogiornos") as paradigmatic examples of these perverse effects. ${ }^{3}$ According to this view, fiscal transfers aimed at reducing income differentials between areas characterized by huge productivity differentials have to be considered among the main culprit of the recent lack of any visible convergence in per capita output between the two "Mezzogiornos" and the rest of their respective countries: "In Germany, early retirement schemes, unemployment benefits, retraining programmes and, in particular, social welfare, have to be mentioned, which all have effectively increased the reservation wage and pulled parts of the

\footnotetext{
${ }^{2}$ Also Decressin and Fatás (1995) find that in Europe regional demand shocks induce large initial participation changes.
} 
labour force away from the regular labour markets. In Italy the situation is very similar, but the emphasis is on different aspects of the welfare system" (Sinn and Westermann, 2001, pp.57-58).

Since the present paper does not aim at studying the effects of a particular aspect of the welfare system, but the overall impact of all those public policies that directly or indirectly redistribute income across households located in different regions, the model presented here assumes that the fiscal authorities collect a fixed proportion of total output and redistribute in equal amount to all the households. In this way, the paper allows to compare a framework in which a centralized authority collects taxes and makes transfers nationwide (or in the whole union) with a framework in which the transfers to the households living in a certain region can be financed only by taxing the economic activities located in that region. It is shown that convergence in per capita output and employment rate among structurally similar regions characterized by different initial conditions can occur only in the absence of interregional redistribution.

\footnotetext{
${ }^{3}$ For a comparison between the two "Mezzogiornos", see Boltho et al. (1997), Sinn and Westermann (2001).
} 
The paper is organized as it follows: section 2 discusses some features of the model in the light of the relevant literature; section 3 presents the model; section 4 characterizes the equilibrium path of the economy; section 5 shows that regional disparities become permanent when there is interregional redistribution; section 6 shows that regional disparities may disappear in the long run when there is no interregional redistribution; section 7 concludes.

\section{BACKGROUND}

A strand of literature emphasizes that region policies and long-lasting inflows of public resources to less developed regions "do not appear to enhance the capacity of these regions, and hence offer no prospect that future transfers will no longer be needed. Instead, they simply redistribute income. If income distribution is a key concern, such transfers will therefore be needed in perpetuity" (Boldrin and Canova, 2001, p. 211). This is because they "facilitate postponement of any necessary adjustment in labour force and relative prices" (Obstfeld and Peri, 1998, p.242). Indeed, "even if inward transfers are initially

motivated by factors that are believed to be transitory, they will inherit 
persistence from the persistence of unemployment, and are likely themselves to induce even greater persistence in unemployment, with further positive feedback to transfers" (Obstfeld and Peri, 1998, p.246). ${ }^{4}$ In brief, "open-ended transfers... are not a mode of regional adjustment to permanent shocks. Instead they finance regional non-adjustment indefinitely" (Obstfeld and Peri, 1998, p.211, italics in the original).

In other words, interregional fiscal transfers are deemed to prevent the adjustment process suggested by the convergence hypothesis (Solow, 1956; Barro and Sala-i-Martin, 1992) form taking place: they eliminate (or considerably reduce) the incentives inducing the reallocation of production factors, which in the presence of non-increasing returns to scale are supposed to gradually suppress the interregional differentials in the factors' rates of return.

The effects of fiscal transfers on regional imbalances are studied in this paper by taking capital mobility into consideration, differently from those neoclassical growth models that are not well equipped to focus on regional convergence because they assume a fully internal capital formation from

\footnotetext{
${ }^{4}$ Hence, "the sharp distinction... between the redistribution and stabilization functions of fiscal
} 
domestic savings. However, the model presented here abstracts from interregional labor mobility, since the experience of the last decades makes unrealistic to imagine that in Europe labor flows may play an important role in the face of territorial disparities.

The other important feature that differentiates this paper from most models explaining convergence or divergence is that the latter assume full employment, thus having little to say about persistent interregional differences in unemployment and labor force participation rates. In contrast, the present paper introduces a mechanism that tends to generate persistence in employment rate differentials across structurally similar regions. Indeed, the existence of long-lasting disparities prompts one to search for resources strategic for growth whose endowments in a certain area depend on local history, since their geographical mobility is somehow limited. This is particularly the case of those assets embodied in human beings and in communities (informal and tacit knowledge, social capital, moral and ethical values, etc.). In Europe, where population mobility across regions is very low, some of these factors are more 
"quasi-fixed" than elsewhere. Therefore, the persistence-causing mechanism formalized here emphasizes that the availability of experienced and trained workers is not independent of history, because experience and training can be acquired by working, and because there are important barriers to interregional labor mobility. Thus, the existence in the past of jobs which offered opportunities for acquiring experience and skills increases the endowment of human capital currently existing in a region, thereby raising aggregate productivity. ${ }^{5}$ In turn, the existence of an abundant supply of skilled labor encourages firms' investment in the area, thus giving rise to a virtuous circle. But, even if formal education cannot substitute for learning by doing, it is a precondition for it: possession of basic formal education is necessary to be able to learn on the job. ${ }^{6}$ This implies that a certain investment is required of a worker

\footnotetext{
5 Empirical data seem to confirm the contribution made to total factor productivity by the learning process which takes place when machinery and technologies are used (see, for example, De Long and Summers, 1992). There is also empirical support for the hypothesis that a shortage of qualified workers has negative effects on productivity growth (for microeconometric evidence concerning the United Kingdom, see Haskel and Martin, 1996).

${ }^{6}$ This complementarity is supported by OECD (1991), which emphasizes that on average less formal schooling seems to lead to more limited training opportunities and possibilities to augment human capital. In the model, this strict complementarity is captured by assuming that a worker can be hired by a good firm which gives him/her training on the job only if s/he has
} 
so that $\mathrm{s} / \mathrm{he}$ can become trainable on the job, or - more in general - so that s/he can become "employable". The expected return on this investment, and/or on the implicit investment that a worker undertakes when s/he accepts a relatively low entry-wage so as to receive training on the job, is increased by the abundance of good job opportunities to which the worker can have access once trained. In turn, the availability of an abundant supply of trainable labor accentuates the firms' propensity to invest in the area, thus reinforcing the virtuous circle. Hence, a mechanism causing persistence (on-the-job training) interacts with the presence of strategic complementary between investors' decisions on (physical) capital accumulation and workers' decisions on investing to become employable. ${ }^{7}$

Even if there are forces pushing toward the perpetuation of regional disparities, convergence in per capita output and employment rate across regions may still be possible when the non-labor sources of income (the

invested in becoming trainable, i.e., if s/he has invested in order to participate actively in the good job market.

Among the models emphasizing the presence of strategic complementaries between investment in physical capital, in $\mathrm{R} \& \mathrm{D}$, or in job creation, on the one hand, and investment to acquire the required human capital and to conduct a job search on the other, see Burdett and Smith, 1995; Acemoglu, 1996; Redding, 1996; Snower, 1996. 
"outside option") of the workers living in the poorer areas are lower than those of the workers located in the richer areas. Indeed, this leads to lower wages in the less developed regions, thus making these areas more attractive for investment in (physical) capital. This is why fiscal transfers and welfare entitlements that tend to equalize the workers' outside option across regions may hinder the process of convergence. ${ }^{8}$ In this regard, the paper can contribute to the debate on the geographical level at which wage bargaining should occur. Indeed, it is shown that decentralizing the wage-setting process at the local level is not sufficient to differentiate wages according to local labor-market conditions, ${ }^{9}$ if fiscal transfers and welfare entitlements equalize the outside option of workers living in areas characterized by different levels of GDP per capita and employment rates. Hence, on this issue, the conclusions of the paper support the position of those who argue that decentralized bargaining would not help very much unless the social system is reformed.(e.g. Sinn and Westermann, 2001).

\footnotetext{
${ }^{8}$ Fiscal transfers and taxes affect employment by changing the ratio between the income conditional on working and the income conditional on non working (see Phelps, 1997; Pissarides, 1998).
} 
The model also limits its analysis to regions that are structurally similar, i.e., that share the same parameter values and differ only with respect to their initial levels of per capita income and employment rates. This is consistent with the viewpoint according to which it is 'reasonable to look for convergence or divergence only among regions that are relatively similar to each other, if not in territorial size at least in the composition of their natural endowment, population, location, geographical structure, climate, access to natural resources, political regimes and so on" (Boldrin and Canova, 2001, p.212). Following this philosophy, the analysis is limited to the case in which the fraction of GDP that is redistributed is equal across regions, even when income transfers to residents in a certain region can be financed only through the taxes collected within that region. This allows to focus exclusively on the long-term implications of the geographical level (central versus local) at which income redistribution occurs, leaving apart the question concerning the long-term effects of changes in the fraction of GDP that is redistributed via fiscal policies.

\footnotetext{
${ }^{9}$ For a model showing that centralized wage-setting should be discouraged and skilled labor
} 


\section{THE MODEL}

In the infinite-horizon economy under consideration, there are firms (that produce by renting physical capital), investors (that are the owners of the productive assets) and workers (that consume their entire income). The economy consists of $\mathbf{J}$ regions, $\mathrm{J} \geq 2$. All regions share the same structural and institutional features: they are assumed to have the same parameter values and modalities of wage determination. Thus, the regions may differ only with respect to their initial conditions.

\section{Population's dynamics}

Time is discrete, and individuals are finitely lived: they have a strictly positive and constant probability $\sigma(0<\sigma<1)$ of dying in each period t. Thus, the probability of dying in a certain period is assumed to be independent of the age of the individual; and it is also assumed that the mortality rate of each large group of individuals does not fluctuate stochastically even though each individual' sifespan is uncertain. This implies that at the end of $t$ a constant fraction $\sigma$ of individuals living in region $\mathrm{j}$ dies, while a new cohort is born at the

mobility should be favoured in order to foster regional convergence, see Faini (1999). 
beginning of the following period. Assuming that $\xi(0<\xi<1)$ is the birth rate, the workers' population $\mathrm{P}_{\mathrm{jt}}$ evolves in each region according to

$$
\mathrm{P}_{\mathrm{jt}+1}=\mathrm{P}_{\mathrm{jt}}(1-\xi+\sigma), \mathrm{P}_{\mathrm{j} 0} \text { given } \forall \mathrm{j}
$$

The firms

In each region, there is a continuum--of measure $n>0$--of locations. In each location $\mathrm{i} \in[0, \mathrm{n}]$ there is a large number (normalized to be one) of identical firms. Locations differ with respect to the specific shock affecting them in each period. Indeed, in each period t the representative firm located in i produces some amount of $Y_{t}$, which is the unique good produced in this economy (the numéraire of the system), according to the constant-returns-to-scale technology

$$
\mathrm{Y}_{\mathrm{jit}}=\mathrm{x}_{\mathrm{it}} \mathrm{K}_{\mathrm{jit}}^{1-\alpha}\left(\mathrm{S}_{\mathrm{jit}}+\Omega \mathrm{A}_{\mathrm{jit}}\right)^{\alpha}, 0<\alpha<1,0<\Omega<1
$$

where $x_{i t}$ is a random variable taking a value in $t$ which is specific to the $i$ location, $\mathrm{K}_{\mathrm{jit}}$ is the physical capital that the $\mathrm{i}$ firm borrowed at the beginning of $\mathrm{t}$ to carry out production, $\mathrm{S}_{\mathrm{jit}}$ are the experienced workers (the "skilled workers") employed by the $\mathrm{i}$ firm in $\mathrm{t}, \mathrm{A}_{\mathrm{jit}}$ are the newly hired workers (the "apprentices") of the $\mathrm{i}$ firm in t. Note that the apprentices are less productive 
than the experienced workers $(\Omega<1)$, and that aggregate output in region $\mathrm{j}$ is given by $\mathrm{Y}_{\mathrm{jt}}=\int_{0}^{\mathrm{n}} \mathrm{Y}_{\mathrm{jit}} \mathrm{di}$.

The random variable $\mathrm{x}_{\mathrm{it}}$ is assumed to be uniformly distributed on the interval $[0, \mathrm{n}]$. Moreover, it is identically distributed across locations and periods, and independently distributed across periods. In each $t, x_{i t}$ takes a different value in each location, with $\mathrm{x}_{\text {it }}$ varying continuously across locations. This implies that the average value of $\mathrm{x}_{\mathrm{it}}$ across locations is not a random variable and does not fluctuate in time, even though individual firms are uncertain about their local $\mathrm{x}_{\mathrm{it}}$ (no aggregate uncertainty). ${ }^{10}$

Assuming that there is a tax on output, the period net profits $\pi_{\mathrm{jit}}^{\mathrm{n}}$ (after taxes and net of the cost of capital) of the i firm are given by:

$$
\pi_{\mathrm{jit}}^{\mathrm{n}}=\pi_{\mathrm{jit}}^{\mathrm{g}}-\left(\mathrm{r}_{\mathrm{t}}+\delta\right) \mathrm{K}_{\mathrm{jit}}, 0<\delta<1
$$

\footnotetext{
${ }^{10}$ In other words, if $\mathrm{K}_{\mathrm{jit}}=\mathrm{K}_{\mathrm{jt}} / \mathrm{n}, \mathrm{S}_{\mathrm{jit}}=\mathrm{S}_{\mathrm{jt}} / \mathrm{n}$ and $\mathrm{A}_{\mathrm{jit}}=\mathrm{A}_{\mathrm{jt}} / \mathrm{n} \forall \mathrm{i}$, then $\mathrm{Y}_{\mathrm{jt}}=\mathrm{n} / 2 \mathrm{~K}_{\mathrm{jt}}^{1-\alpha}\left(\mathrm{S}_{\mathrm{jt}}+\Omega \mathrm{A}_{\mathrm{jt}}\right)^{\alpha}$
} 
where $\pi_{\mathrm{jit}}^{\mathrm{g}}=(1-\tau) \mathrm{Y}_{\mathrm{jit}}-\mathrm{v}_{\mathrm{jit}} \mathrm{S}_{\mathrm{jit}}-\mathrm{e}_{\mathrm{jit}} \mathrm{A}_{\mathrm{jit}}, 0<\tau<1$, are the firm' $\mathrm{s}$ gross profits $\tau$ is the (fixed) tax rate, $v_{j i t}$ is the real wage paid by the $i$ firm to the skilled workers employed in $\mathrm{t}, \mathrm{e}_{\mathrm{jit}}$ is the entry wage paid by the $\mathrm{i}$ firm to the apprentices hired in $\mathrm{t}, \delta$ is a capital depreciation parameter, and $r_{t}$ is the (real) interest rate, i.e. the market rate at which firms borrowed capital at the beginning of period t. Interest payment and reimbursement of principal are due at the end of t. The interest rate is unique because capital is perfectly mobile across regions and locations at the beginning of each period, while mobility is infinitely costly within the period: once borrowed and installed at the beginning of $t$, a firm' s capital stock must remain fixed until the end of $\mathrm{t}$.

The investors

There is a large number (normalized to be one) of identical investors who are the firms' o wners: for simplicity and without loss of generality, it is assumed that all investors are entitled to receive an equal share of the firms' n et profits. Being the owners of the firms' productive assets, investors must decide in each $t$ what fraction of their gross returns on wealth to spend on consumption 
rather than on buying productive assets to be lent at the beginning of $t+1$ to firms. Hence, the problem of the representative investor amounts to deciding a contingency plan for consumption $C_{t}^{\text {in }}$ and holding of productive assets $K_{t+1}$ in order to maximize his/her lifetime expected sequence of discounted period utilities:

$$
\sum_{\mathrm{t}=0}^{\infty} \theta^{\mathrm{t}} \frac{\left(\mathrm{C}_{\mathrm{t}}^{\mathrm{in}}\right)^{1-\zeta}}{1-\zeta}, \zeta \geq 0, \theta \equiv \gamma(1-\sigma), 0<\gamma \leq 1
$$

subject to $\mathrm{K}_{\mathrm{t}+1}+\mathrm{C}_{\mathrm{t}}^{\mathrm{in}} \leq\left(1+\mathrm{r}_{\mathrm{t}}\right) \mathrm{K}_{\mathrm{t}}+\pi_{\mathrm{t}}^{\mathrm{n}}, \mathrm{K}_{0}$ given, $\pi_{\mathrm{t}}^{\mathrm{n}}=\sum_{\mathrm{j}=1}^{\mathrm{J}} \int_{0}^{\mathrm{n}} \pi_{\mathrm{jit}}^{\mathrm{n}} d \mathrm{i}$.

In (4), $\zeta$ is the relative-risk-aversion parameter, $\gamma$ is a time-preference parameter and $\pi_{\mathrm{t}}^{\mathrm{n}}$ are aggregate (net) profits. Expectations are rational, in the sense that they are consistent with the model and are generated by optimally processing the available information. Since there is uncertainty only at the local level, investors have perfect foresight on the behavior of aggregate variables. It is also worth to note that it is immaterial where the investors are located, since there is a single market for capital and a single market for the only good produced in 
this J-regions economy (no transportation cost). Finally -- for simplicity and without loss of generality - it is ruled out the existence of actuarially fair annuities paid to the living investors by a financial institution collecting their wealth as they die: the wealth of someone who dies is inherited by some newly born individual (accidental bequests).

The skilled workers

Skilled workers are those who have been trained on the job while working in a firm for at least one period. In contrast, apprentices are workers with no work experience in the formal economy, but who have been hired by a firm after having invested to acquire the required basic knowledge. In their working lives, workers never lose the general skills that they have acquired. Being general, the skills acquired on the job are perfectly transferable. However, it is assumed that interregional labor mobility is infinitely costly. Thus, the skilled labor force evolves in each region according to

$$
\mathrm{M}_{\mathrm{jt}+1}=(1-\sigma)\left(\mathrm{M}_{\mathrm{jt}}+\mathrm{A}_{\mathrm{jt}}\right), \mathrm{M}_{\mathrm{jt}}=\int_{0}^{\mathrm{n}} \mathrm{M}_{\mathrm{jit}} d \mathrm{i}, \mathrm{M}_{\mathrm{j} 0} \text { given } \forall \mathrm{j}, \mathrm{A}_{\mathrm{jt}}=\int_{0}^{\mathrm{n}} \mathrm{A}_{\mathrm{jit}} d \mathrm{i},
$$

where $\mathrm{M}_{\mathrm{jit}}$ are the skilled workers of region $\mathrm{j}$ located in $\mathrm{i}$ during period $\mathrm{t}$. 
As in Blanchflower and Oswald (1994), workers choose location (within their region) ex ante (at the beginning of each $t$ ), while firms decide on labor input once uncertainty is resolved. As for capital, labor is perfectly mobile across locations (of the same region) at the beginning of each period $t$, while mobility across locations is infinitely costly within one period. ${ }^{11}$

Once located in i, a skilled worker has the following period expected utility:

$$
\mathrm{u}_{\mathrm{jit}}^{\mathrm{sk}}=\mathrm{E}_{\mathrm{t}}\left[\mathrm{p}_{\mathrm{jit}} u\left(\mathrm{w}_{\mathrm{jt}}+\mathrm{v}_{\mathrm{jit}}\right)+\left(1-\mathrm{p}_{\mathrm{jit}}\right) u\left(\eta_{\mathrm{wt}}\right)\right], u^{\prime}>0, u^{\prime \prime} \leq 0, \eta>1,
$$

where $E_{t}$ is an expectation operator conditional on the information available in $t$ as the realization of $\mathrm{x}_{\mathrm{it}}$ is not yet known, $\mathrm{w}_{\mathrm{jt}}$ is the workers' non-labor income (namely the monetized value of the welfare entitlements and government transfers made to all workers of region $\mathrm{j}$ ), and $\mathrm{p}_{\mathrm{jit}}$ is the fraction of the skilled workforce located in i that is employed in $\mathrm{t}$ :

$$
p_{j i t}=\left\{\begin{array}{l}
\frac{S_{j i t}}{M_{j i t}} \text { if } S_{j i t} \leq M_{j i t} \\
1 \text { otherwise. }
\end{array}\right.
$$

\footnotetext{
${ }^{11}$ This short-term immobility implies that in period $\mathrm{t}$ a worker located in i does not work at all
} 
Finally, $\eta>1$ captures the fact that an unemployed worker can enjoy more leisure (and/or undertake some activity in the informal segment of the labor market).

At the beginning of each period, a skilled worker decides in what location to stay (within his/her region). Obviously, s/he locates where s/he can expect to enjoy the highest lifetime utility. Therefore, the discounted sequence of utilities that an optimizing skilled worker can expect (before the realization of $\mathrm{x}_{\mathrm{it}}$ ) to gain in the rest of his/her lifetime is given by

$$
\mathrm{U}_{\mathrm{jt}}^{\mathrm{sk}}=\mathrm{u}_{\mathrm{ji}{ }^{*} \mathrm{t}}^{\mathrm{sk}}+\phi \mathrm{U}_{\mathrm{jt}+1}^{\mathrm{sk}}, \phi \equiv \beta(1-\sigma), 0<\beta<1 .
$$

In (8), $\beta$ is a time-preference parameter, and $i^{*}$ is the location where a skilled worker living in region $\mathrm{j}$ can have the best prospects (a "best location"): ${ }^{12}$ $\mathrm{u}_{\mathrm{ji} * \mathrm{t}}^{\mathrm{sk}} \geq \mathrm{u}_{\mathrm{jit}}^{\mathrm{sk}} \forall \mathrm{i}$.

\section{The trainable workers}

An investment in human capital at the beginning of period $t$ in order to become "trainable" (or "employable" in the formal segment of the labor market)

in the formal economy if s/he is not employed in that period by a firm of $i$.

${ }^{12}$ More than one location can share this status of best location. 
yields a strictly positive probability of being employed by a firm only in that period, since the basic knowledge acquired by a person is dissipated if it is not used on the job. Moreover, possession of the basic knowledge required by the firms has no value in the informal economy. Hence, the investment made in order to participate in the formal labor market will be lost, if within one period, the worker does not find an entry job paid at least as his/her reservation wage: after having invested in human capital, a trainable worker will accept any job offer paying an entry wage larger than his/her reservation wage $\mathrm{e}_{\mathrm{jit}}^{\min }$. Finally, also a trainable worker decides to stay in that location within his/her region where s/he can expect to enjoy the highest lifetime utility. Thus, the discounted sequence of utilities that an optimizing trainable worker can expect (before the realization of $x_{i t}$ ) to gain in the rest of his/her lifetime is given by

$$
\mathrm{U}_{\mathrm{jt}}^{\mathrm{tr}}=\mathrm{E}_{\mathrm{t}}\left\{\mathrm{q}_{\mathrm{ji} *_{\mathrm{t}}}\left[u\left(\mathrm{w}_{\mathrm{jt}}+\mathrm{e}_{\mathrm{ji} *_{\mathrm{t}}}\right)+\phi \mathrm{U}_{\mathrm{jt}+1}^{\mathrm{sk}}\right]+\left(1-\mathrm{q}_{\mathrm{ji} * \mathrm{t}}\right)\left[u\left(\eta \mathrm{w}_{\mathrm{jt}}\right)+\phi \mathrm{U}_{\mathrm{jt}+1}^{\mathrm{un}}\right]\right\} .
$$

In (9), $\mathrm{U}_{\mathrm{jt}+1}^{\mathrm{un}}$ is the discounted sequence of utilities that an optimizing unskilled worker still alive at the beginning of $t+1$ can expect to get in the rest of his/her lifetime, $u\left(\mathrm{w}_{\mathrm{jt}}+\mathrm{e}_{\mathrm{jit}}\right) \geq u\left(\mathrm{w}_{\mathrm{jt}}+\mathrm{e}_{\mathrm{jt}}^{\mathrm{min}}\right) \equiv u\left(\eta \mathrm{w}_{\mathrm{jt}}\right)-\phi\left(\mathrm{U}_{\mathrm{jt}+1}^{\mathrm{sk}}-\mathrm{U}_{\mathrm{jt}+1}^{\mathrm{un}}\right), \mathrm{i}^{*}$ is a best 
location for a trainable worker living in region $\mathrm{j}^{13}$ and $\mathrm{q}_{\mathrm{jit}}$ is the fraction of the trainable workforce located in $\mathrm{i}$ that is hired in period $\mathrm{t}$ :

$$
\mathrm{q}_{\mathrm{jit}}=\left\{\begin{array}{l}
\frac{\mathrm{A}_{\mathrm{jit}}}{\mathrm{L}_{\mathrm{jit}}} \text { if } \mathrm{A}_{\mathrm{jit}} \leq \mathrm{L}_{\mathrm{jit}} \\
1 \text { otherwise, }
\end{array}\right.
$$

where $\mathrm{L}_{\mathrm{jit}}$ is the trainable workforce located in $\mathrm{i}$.

The unskilled workers

At the beginning of each period, an unskilled worker must decide whether to incur the utility loss associated with participation in the formal labor market (i.e., with the acquisition of the basic knowledge required by the firms operating in the formal economy $)^{14}$ or to remain out of the formal labor market: an unskilled worker can be hired by a firm only if s/he becomes trainable. An unskilled worker who decides not to invest in human capital has the same lifetime prospects as a trainable worker who does not find an entry job after

${ }^{13} \mathrm{E}_{\mathrm{t}}\left\{\mathrm{q}_{\mathrm{ji} * \mathrm{t}}\left[u\left(\mathrm{w}_{\mathrm{jt}}+\mathrm{e}_{\mathrm{ji}{ }^{*} \mathrm{t}}\right)+\phi \mathrm{U}_{\mathrm{jt}+1}^{\mathrm{sk}}\right]+\left(1-\mathrm{q}_{\mathrm{ji} * \mathrm{t}}\right)\left[u\left(\eta \mathrm{w}_{\mathrm{jt}}\right)+\phi \mathrm{U}_{\mathrm{jt}+1}^{\mathrm{un}}\right]\right\} \geq$
$\geq \mathrm{E}_{\mathrm{t}}\left\{\mathrm{q}_{\mathrm{jit}}\left[u\left(\mathrm{w}_{\mathrm{jt}}+\mathrm{e}_{\mathrm{jit}}\right)+\phi \mathrm{U}_{\mathrm{jt}+1}^{\mathrm{sk}}\right]+\left(1-\mathrm{q}_{\mathrm{jit}}\right)\left[u\left(\eta \mathrm{w}_{\mathrm{jt}}\right)+\phi \mathrm{U}_{\mathrm{jt}+1}^{\mathrm{un}}\right]\right\} \forall \mathrm{i}$

${ }^{14}$ Alternatively, one may interpret this disutility as due to the direct and indirect costs of searching an entry job in the formal segment of the labor market. 
having incurred the utility loss entailed by this investment. Therefore, an optimizing unskilled worker can expect at the beginning of t to get the lifetime discounted sequence of utilities associated with the best available alternative:

$$
\mathrm{U}_{\mathrm{jt}}^{\mathrm{un}}=\max \left\{h(\mathrm{c})+\mathrm{U}_{\mathrm{jt}}^{\mathrm{tr}}, u\left(\eta \mathrm{w}_{\mathrm{jt}}\right)+\phi \mathrm{U}_{\mathrm{jt}+1}^{\mathrm{un}}\right\}, h>0,
$$

where $-h(\mathrm{c})$, captures the disutility of acquiring the required basic knowledge (c is the monetized value of this disutility).

\section{Wage determination}

An insider-outsider scenario is considered. In each location, the wages are determined by negotiations held at the beginning of every period between a local union unconcerned about the interests of workers with no work experience and the local employers' association. In this context, it is immaterial whether the unions are only concerned about the workers employed in the previous period, or about both the latter and those experienced workers who were laid off in previous periods. In fact, even if the wage setters do not care about the interests of the skilled workers on layoff, the latter put pressure on them, insofar as they are perfect substitutes and thereby reduce the job security of the employed. 
The union operating in $i$ negotiates the real wage that all the firms of $i$ must pay to the experienced workers in employment, while each individual firm takes its decisions on the demand for labor and capital in full autonomy. This negotiation also concerns the entry wage, which is established as the fixed fraction $\mu$ of the skilled workers' wage that firms must pay to the apprentices $\left(\mathrm{e}_{\mathrm{jit}}=\mu \mathrm{v}_{\mathrm{jit}}\right)$. It is realistic to assume that the union does not allow the wage differential between skilled workers and apprentices fully to offset their productivity differential $(\Omega<\mu \leq 1)$, so that any incentive for the employers to replace experienced workers with apprentices is suppressed. ${ }^{15}$

The bargaining process can be represented as if each union unilaterally sets the real wage in the awareness of its impact on the local firms' d ecisions. On the other hand, each union is aware that the effects of its wage policy on the economy as a whole is negligible. Similarly, each single firm perceives that its decisions on labor and capital input cannot influence the wage setting process because their impact is insignificant relatively to the size of the local labor

\footnotetext{
${ }^{15}$ Burdett and Smith (1995) emphasize that the key assumption for the existence of a low skill trap is that an employer' sprofit flow is greater when employing a skilled worker than when employing an unskilled worker. Indeed, the fact that firms lay off unskilled workers before
} 
market. Since the real wage, once negotiated, remains fixed for a certain lapse of time (a "period"), it is reasonable to assume that the wage is set by the union before the realization of the random variable that is relevant for that period.

Within this decentralized wage setting, in each $\mathrm{t}$ the local union operating in i must solve the following problem:

$$
\max _{\mathrm{v}_{\mathrm{jit}}} \mathrm{u}_{\mathrm{jit}}^{\mathrm{sk}}+\phi \mathrm{U}_{\mathrm{jt}+1}^{\mathrm{sk}} \cdot
$$

In each period the union has full control only over the current wage, if we maintain that current union membership cannot commit the workers who will manage the union in the future to the pursuit of policies not optimal from their own temporal perspective. In other words, a wage policy is feasible only if it is time consistent. Hence, the union' s problem can be decomposed into a sequence of similar problems that can be solved recursively.

\section{Redistributive policies}

We consider two possible institutional setups for income redistribution.

skilled workers is difficult to reconcile with the contention that unskilled workers are more profitable. 
In the first one, there is a centralized fiscal authority that collects taxes throughout the economy and provides the same welfare benefit for all workers living in the economy (interregional redistribution):

$$
\mathrm{w}_{1 \mathrm{t}}=\mathrm{w}_{2 \mathrm{t}}=. .=\mathrm{w}_{\mathrm{Jt}}=\mathrm{w}_{\mathrm{t}}=\frac{\tau \sum_{\mathrm{j}=1}^{\mathrm{J}} \mathrm{Y}_{\mathrm{jt}}}{\sum_{\mathrm{j}=1}^{\mathrm{J}} \mathrm{P}_{\mathrm{jt}}} .
$$

In the alternative scenario, in each region there is a fiscal authority collecting taxes within the region and providing the same welfare benefit for all workers living in that region (no interregional redistribution):

$$
\mathrm{w}_{\mathrm{jt}}=\tau \mathrm{Y}_{\mathrm{jt}} / \mathrm{P}_{\mathrm{jt}}
$$

\section{A summary of the timing of events}

Summarizing, in each $t$ we have a sequence of events in the following order: i) a new cohort enters the economy; ii) unskilled workers decide whether to invest in order to become trainable; iii) firms borrow physical capital for carrying out production, the workers decide where to locate; iv) unions set the wage; v) idiosynchratic shocks occur; vi) firms atomistically determine their 
demand for skilled workers and apprentices, production takes place, apprentices are trained on the job, taxes are collected and transfers payments are made; vii) firms reimburse the principal and pay the interest on the capital borrowed at the beginning of the period, firms also pay the dividends to the shareholders, investors decide what fraction of their income to save, a fraction $\sigma$ of each group of population dies at the end of the period.

\section{CHARACTERIZATION OF AN EQUILIBRIUM PATH}

Equilibrium conditions in the markets for product and physical capital

One can easily derive the conditions for equilibrium both in the product market and in the market for productive assets:

$$
\begin{gathered}
\sum_{\mathrm{j}=1}^{\mathrm{J}} \mathrm{Y}_{\mathrm{jt}}+(1-\delta) \mathrm{K}_{\mathrm{t}}=\mathrm{K}_{\mathrm{t}+1}+\mathrm{C}_{\mathrm{t}}^{\mathrm{in}}+\sum_{\mathrm{j}=1}^{\mathrm{J}} \mathrm{C}_{\mathrm{jt}}^{\mathrm{w}}, \\
\mathrm{K}_{\mathrm{t}+1}=\sum_{\mathrm{j}=1}^{\mathrm{J}} \int_{0}^{\mathrm{n}} \mathrm{K}_{\mathrm{jit}+1} d \mathrm{i},
\end{gathered}
$$


where $\mathrm{C}_{\mathrm{jt}}^{\mathrm{w}}=\mathrm{P}_{\mathrm{jt}} \mathrm{W}_{\mathrm{jt}}+\int_{0}^{\mathrm{n}}\left(\mathrm{v}_{\mathrm{jit}} \mathrm{S}_{\mathrm{jit}}+\mathrm{e}_{\mathrm{jit}} \mathrm{A}_{\mathrm{jit}}\right) d \mathrm{i}$ is the consumption of the workers living in $\mathrm{j}$.

Firms' optimality condition for capital accumulation

Firms of $i$ determine their demand for capital at the beginning of $t$ by satisfying the optimality condition

$$
\mathrm{E}_{\mathrm{t}}\left[\frac{\partial \pi^{\mathrm{g}}\left(\mathrm{x}_{\mathrm{it}}, \mathrm{M}_{\mathrm{jit}}, \mathrm{k}_{\mathrm{jit}}, \mathrm{s}_{\mathrm{jit}}, \mathrm{v}_{\mathrm{jit}}\right)}{\partial \mathrm{K}_{\mathrm{jit}}}\right]=\mathrm{r}_{\mathrm{t}}+\delta, \mathrm{k}_{\mathrm{jit}} \equiv \mathrm{K}_{\mathrm{jit}} / \mathrm{M}_{\mathrm{jit}}, \mathrm{s}_{\mathrm{jit}} \equiv \mathrm{L}_{\mathrm{jit}} / \mathrm{M}_{\mathrm{jit}},
$$

where the firms' (gross) profit function $\pi^{\mathrm{g}}($.$) is given in (A3).$

This optimality condition defines $\mathrm{k}_{\mathrm{jit}}$, that is the physical capital/skilled labor ratio in the firms of $\mathrm{i}$, as an implicit function of the trainable labor/skilled labor ratio of $i$, the wage and the interest rate:

$$
f\left(\mathrm{k}_{\mathrm{jit}}, \mathrm{s}_{\mathrm{jit}}, \mathrm{v}_{\mathrm{jit}}\right)=\mathrm{r}_{\mathrm{t}}+\delta, f_{1}<0, f_{2}>0 \text { and } f_{3}<0,
$$


where $f()=.\frac{(1-\alpha) \mathrm{v}_{\mathrm{jit}}^{2}\left\{(\mu / \Omega)^{2}\left[1-\left(1+\Omega \mathrm{s}_{\mathrm{jit}}\right)^{2-\alpha}\right]-1\right\}}{2 \mathrm{n} \alpha(2-\alpha)(1-\tau) \mathrm{k}_{\mathrm{jit}}^{2-\alpha}}+\frac{(1-\alpha)(1-\tau) \mathrm{n}}{2\left(1+\Omega \mathrm{s}_{\mathrm{jit}}\right)^{-\alpha} \mathrm{k}_{\mathrm{jit}}^{\alpha}}$ and $\mathrm{v}_{\mathrm{jit}}$ is determined by the union operating in $\mathrm{i}$ according to the time-invariant wage rule (see the Appendix)

$$
\mathrm{v}_{\mathrm{jit}}=v\left(\mathrm{k}_{\mathrm{jit}}, \mathrm{w}_{\mathrm{jt}}\right), v_{\mathrm{k}}>0, v_{\mathrm{w}}>0 .
$$

The lifetime well-being of a skilled worker along an equilibrium path

Using (17) and (A5), one can obtain the equation governing the equilibrium path of the lifetime well-being of a skilled worker:

$$
\mathrm{U}_{\mathrm{jt}}^{\mathrm{sk}}=u^{\mathrm{sk}}\left(v\left(\mathrm{k}_{\mathrm{jt}}, \mathrm{w}_{\mathrm{jt}}\right), \mathrm{k}_{\mathrm{jt}}, \mathrm{w}_{\mathrm{jt}}\right)+\phi \mathrm{U}_{\mathrm{jt} t+1}^{\mathrm{sk}},
$$

where the subscripts denoting the location are dropped. Indeed, an equilibrium pair $\left(\left\{\mathrm{s}_{\mathrm{jt}}\right\}_{0}^{\infty},\left\{\mathrm{k}_{\mathrm{jt}}\right\}_{0}^{\infty}\right)$ satisfying (16)-(18) and (A7) depends on structural parameters assumed to be equal across locations and on exogenously given trajectory of $r_{t}$ and $\mathrm{w}_{\mathrm{jt}}$. Therefore, different locations belonging to the same region display equal physical capital/skilled labor and trainable labor/skilled labor ratios. Hence, local unions operating in the same region are induced to set the same wage in all locations of the region, and workers can be indifferent (ex 
ante) among locations belonging to the same region, expecting the same wellbeing everywhere. ${ }^{16}$

Using (A7), one can rewrite (18) as

$$
\Psi\left(\mathrm{s}_{\mathrm{jt}+1}, \mathrm{k}_{\mathrm{jt}+1}, \mathrm{w}_{\mathrm{jt}+1}, \mathrm{~s}_{\mathrm{jt}}, \mathrm{k}_{\mathrm{jt}}, \mathrm{w}_{\mathrm{jt}}\right)=0,
$$

where $\Psi()=.\frac{h(\mathrm{c})}{\phi q\left(v\left(\mathrm{k}_{\mathrm{jt}}, \mathrm{w}_{\mathrm{jt}}\right), \mathrm{k}_{\mathrm{jt}}, \mathrm{s}_{\mathrm{jt}}\right)}-\frac{h(\mathrm{c})}{q\left(v\left(\mathrm{k}_{\mathrm{jt}+1}, \mathrm{w}_{\mathrm{jt}+1}\right), \mathrm{k}_{\mathrm{jt}+1}, \mathrm{~s}_{\mathrm{jt}+1}\right)}+\frac{u\left(\eta \mathrm{w}_{\mathrm{jt}}\right)}{\phi}-$

$$
-\frac{u\left(\mathrm{w}_{\mathrm{jt}}+\mu v\left(\mathrm{k}_{\mathrm{jt}}, \mathrm{w}_{\mathrm{jt}}\right)\right)}{\phi}-u^{\mathrm{sk}}\left(v\left(\mathrm{k}_{\mathrm{jt}+1}, \mathrm{w}_{\mathrm{jt}+1}\right), \mathrm{k}_{\mathrm{t}+1}, \mathrm{w}_{\mathrm{jt}+1}\right)+u\left(\mathrm{w}_{\mathrm{jt}+1}+\mu v\left(\mathrm{k}_{\mathrm{jt}+1}, \mathrm{w}_{\mathrm{jt}+1}\right)\right) .
$$

\section{Determination of the equilibrium interest rate}

One can determine the time profile of the interest rate by solving the problem of the investors. The investors' optimal plan must satisfy:

$$
\begin{gathered}
\left(\frac{C_{t+1}^{i n}}{C_{t}^{i n}}\right)^{\zeta}=\theta\left(1+r_{t+1}\right), \\
\lim _{t \rightarrow \infty} \theta^{t} K_{t}\left(C_{t}^{\text {in }}\right)^{-\zeta}=0 .
\end{gathered}
$$

Along an equilibrium trajectory, one has:

$$
\mathrm{C}_{\mathrm{t}}^{\mathrm{in}}=\sum_{\mathrm{j}=1}^{\mathrm{J}} \mathrm{M}_{\mathrm{jt}} C\left(\mathrm{w}_{\mathrm{jt}}, \mathrm{k}_{\mathrm{jt}}, \mathrm{s}_{\mathrm{jt}}, \mathrm{k}_{\mathrm{jt}+1}\right)
$$

\footnotetext{
${ }^{16}$ In other words, the equilibrium solution is symmetric across locations.
} 
where

$$
\begin{aligned}
C(.)= & \frac{\left[v\left(\mathrm{k}_{\mathrm{jt}}, \mathrm{w}_{\mathrm{jt}}\right)\right]^{2} \mathrm{k}_{\mathrm{jt}}^{\alpha-1}}{2 \alpha(2-\alpha) \mathrm{n}(1-\tau)}\left\{1+\left(\frac{\mu}{\Omega}\right)^{2}\left[\left(1+\Omega \mathrm{s}_{\mathrm{jt}}\right)^{2-\alpha}-1\right]\right\}+\frac{\mathrm{k}_{\mathrm{jt}}^{1-\alpha} \mathrm{n}(1-\tau)\left(1+\Omega \mathrm{s}_{\mathrm{jt}}\right)^{\alpha}}{2}- \\
& -v\left(\mathrm{k}_{\mathrm{jt}}, \mathrm{w}_{\mathrm{jt}}\right)\left(1+\mu \mathrm{s}_{\mathrm{jt}}\right)+(1-\delta) \mathrm{k}_{\mathrm{jt}}-(1-\sigma)\left[1+\mathrm{s}_{\mathrm{jt}} q\left(v\left(\mathrm{k}_{\mathrm{jt}}, \mathrm{w}_{\mathrm{jt}}\right), \mathrm{k}_{\mathrm{jt}}, \mathrm{s}_{\mathrm{jt}}\right)\right] \mathrm{k}_{\mathrm{jt}+1} \text {. Moreover, }
\end{aligned}
$$

along an equilibrium trajectory, the skilled workforce evolves according to

$$
\mathrm{M}_{\mathrm{jt}+1}=\mathrm{M}_{\mathrm{jt}}\left(1+\rho_{\mathrm{M}_{\mathrm{j} \mathrm{T}}}\right), \rho_{\mathrm{M}_{\mathrm{jt}}} \equiv \frac{\mathrm{M}_{\mathrm{jt}+1}-\mathrm{M}_{\mathrm{jt}}}{\mathrm{M}_{\mathrm{jt}}}, \mathrm{M}_{\mathrm{j} 0} \text { given } \forall \mathrm{j}
$$

where $\rho_{\mathrm{M}_{\mathrm{jT}}}=\rho\left(\mathrm{k}_{\mathrm{jt}}, \mathrm{w}_{\mathrm{jt}}, \mathrm{s}_{\mathrm{jt}}\right)=(1-\sigma)\left[1+\mathrm{s}_{\mathrm{jt}} q\left(v\left(\mathrm{k}_{\mathrm{jt}}, \mathrm{w}_{\mathrm{jt}}\right), \mathrm{k}_{\mathrm{jt}}, \mathrm{s}_{\mathrm{jt}}\right)\right]-1$.

Finally, along an equilibrium trajectory, one has:

$$
\mathrm{Y}_{\mathrm{jt}}=\mathrm{M}_{\mathrm{jt}}\left\{\frac{\left[\mu \nu\left(\mathrm{k}_{\mathrm{jt}}, \mathrm{w}_{\mathrm{jt}}\right)\right]^{2}\left[1-\left(1+\Omega \mathrm{s}_{\mathrm{jt}}\right)^{2-\alpha}\right]-\left[\Omega v\left(\mathrm{k}_{\mathrm{jt}}, \mathrm{w}_{\mathrm{jt}}\right)\right]^{2}}{2 \mathrm{n} \alpha(1-\tau)^{2}(2-\alpha) \Omega^{2} \mathrm{k}_{\mathrm{jt}}^{1-\alpha}}+\frac{\mathrm{nk}_{\mathrm{jt}}^{1-\alpha}\left(1+\Omega \mathrm{s}_{\mathrm{jt}}\right)^{\alpha}}{2}\right\} .
$$




\section{THE EQUILIBRIUM PATH WITH INTERREGIONAL REDISTRIBUTION}

Considering that according to $(13 \mathrm{a}) \mathrm{w}_{1 \mathrm{t}}=\mathrm{w}_{2 \mathrm{t}}=\ldots=\mathrm{w}_{\mathrm{Jt}}=\mathrm{w}_{\mathrm{t}}$, one has $\mathrm{s}_{1 \mathrm{t}}=\mathrm{s}_{2 \mathrm{t}}=. . .=\mathrm{s}_{\mathrm{Jt}}=\mathrm{s}_{\mathrm{t}}$ and $\mathrm{k}_{1 \mathrm{t}}=\mathrm{k}_{2 \mathrm{t}}=. .=\mathrm{k}_{\mathrm{Jt}}=\mathrm{k}_{\mathrm{t}} \forall \mathrm{t}$. Hence, one can use (23) to write (13a) as

$$
\mathrm{w}_{\mathrm{t}}=\tau_{\mathrm{t}}\left\{\frac{\left[\mu \nu\left(\mathrm{k}_{\mathrm{t}}, \mathrm{w}_{\mathrm{t}}\right)\right]^{2}\left[1-\left(1+\Omega \mathrm{s}_{\mathrm{t}}\right)^{2-\alpha}\right]-\left[\Omega v\left(\mathrm{k}_{\mathrm{t}}, \mathrm{w}_{\mathrm{t}}\right)\right]^{2}}{2 \mathrm{n} \alpha(1-\tau)^{2}(2-\alpha) \Omega^{2} \mathrm{k}_{\mathrm{t}}^{1-\alpha}}+\frac{\mathrm{nk}_{\mathrm{t}}^{1-\alpha}\left(1+\Omega \mathrm{s}_{\mathrm{t}}\right)^{\alpha}}{2}\right\}
$$

where $b_{t} \equiv \frac{\sum_{j=1}^{J} M_{j t}}{\sum_{j=1}^{J} P_{j t}}$ is the skilled labor-workers' population ratio of the entire economy. Equation (24) allows to implicitly define $\mathrm{w}_{\mathrm{t}}$ as a function of $\mathrm{k}_{\mathrm{t}}, \mathrm{s}_{\mathrm{t}}$ and $b_{t}$ :

$$
\mathrm{w}_{\mathrm{t}}=w\left(\mathrm{k}_{\mathrm{t}}, \mathrm{s}_{\mathrm{t}}, \mathrm{b}_{\mathrm{t}}\right)
$$

Moreover, the ratio $b_{t}$ evolves according to

$$
\chi\left(\mathrm{b}_{\mathrm{t}+1}, \mathrm{~b}_{\mathrm{t}}, \mathrm{k}_{\mathrm{t}}, \mathrm{w}_{\mathrm{t}}, \mathrm{s}_{\mathrm{t}}\right)=\mathrm{b}_{\mathrm{t}+1}-\mathrm{b}_{\mathrm{t}} \frac{\left[1+\rho\left(\mathrm{k}_{\mathrm{t}}, \mathrm{w}_{\mathrm{t}}, \mathrm{s}_{\mathrm{t}}\right)\right]}{(1-\sigma+\xi)}=0, \mathrm{~b}_{0} \text { given, }
$$

where $\rho($.$) is given by (22).$ 
Considering that $\mathrm{w}_{1 \mathrm{t}}=\mathrm{w}_{2 \mathrm{t}}=. .=\mathrm{w}_{\mathrm{Jt}}=\mathrm{w}_{\mathrm{t}}, \quad \mathrm{s}_{1 \mathrm{t}}=\mathrm{s}_{2 \mathrm{t}}=. .=\mathrm{s}_{\mathrm{Jt}}=\mathrm{s}_{\mathrm{t}} \quad$ and $\mathrm{k}_{1 \mathrm{t}}=\mathrm{k}_{2 \mathrm{t}}=. .=\mathrm{k}_{\mathrm{Jt}}=\mathrm{k}_{\mathrm{t}} \forall \mathrm{t}$, one can use (21)-(22) to rewrite (20a) as

$$
\frac{\left[1+\rho\left(\mathrm{k}_{\mathrm{t}}, \mathrm{w}_{\mathrm{t}}, \mathrm{s}_{\mathrm{t}}\right)\right]^{\zeta}\left[C\left(v\left(\mathrm{k}_{\mathrm{t}+1}, \mathrm{w}_{\mathrm{t}+1}\right), \mathrm{k}_{\mathrm{t}+1}, \mathrm{~s}_{\mathrm{t}+1}, \mathrm{k}_{\mathrm{t}+2}\right)\right]^{\zeta}}{\left[C\left(v\left(\mathrm{k}_{\mathrm{t}}, \mathrm{w}_{\mathrm{t}}\right), \mathrm{k}_{\mathrm{t}}, \mathrm{s}_{\mathrm{t}}, \mathrm{k}_{\mathrm{t}+1}\right)\right]^{\zeta}}=\theta\left(1+\mathrm{r}_{\mathrm{t}}\right) .
$$

Given equations (16), (17) and (27), the condition for equilibrium in the capital market becomes

$$
\begin{aligned}
& \Phi\left(\mathrm{k}_{\mathrm{t}+2}, \mathrm{~s}_{\mathrm{t}+1}, \mathrm{k}_{\mathrm{t}+1}, \mathrm{w}_{\mathrm{t}+1}, \mathrm{~s}_{\mathrm{t}}, \mathrm{k}_{\mathrm{t}}, \mathrm{w}_{\mathrm{t}}\right)=f\left(\mathrm{k}_{\mathrm{t}+1}, \mathrm{~s}_{\mathrm{t}+1}, v\left(\mathrm{k}_{\mathrm{t}+1}, \mathrm{w}_{\mathrm{t}+1}\right)\right)+1-\delta- \\
& -\frac{\left[1+\rho\left(\mathrm{k}_{\mathrm{t}}, \mathrm{w}_{\mathrm{t}}, \mathrm{s}_{\mathrm{t}}\right)\right]^{\zeta}\left[C\left(v\left(\mathrm{k}_{\mathrm{t}+1}, \mathrm{w}_{\mathrm{t}+1}\right), \mathrm{k}_{\mathrm{t}+1}, \mathrm{~s}_{\mathrm{t}+1}, \mathrm{k}_{\mathrm{t}+2}\right)\right]^{\zeta}}{\theta\left[C\left(v\left(\mathrm{k}_{\mathrm{t}}, \mathrm{w}_{\mathrm{t}}\right), \mathrm{k}_{\mathrm{t}}, \mathrm{s}_{\mathrm{t}}, \mathrm{k}_{\mathrm{t}+1}\right)\right]^{\zeta}}=0 .
\end{aligned}
$$

One can use (25) to substitute for $\mathrm{w}_{\mathrm{t}}$ in (19), (26) and (28), thus obtaining the system of difference equations in $\mathrm{k}_{\mathrm{t}}, \mathrm{s}_{\mathrm{t}}$ and $\mathrm{b}_{\mathrm{t}}$ that governs the general equilibrium path of the economy under fiscal centralism. Along this path, the following proposition holds: 
Proposition 1 In the presence of interregional redistribution (fiscal centralism), initial differentials across regions in per capita output and employment rates are preserved forever even if these regional economies are structurally similar (i.e., even if they have the same parameter values).

To verify that Proposition 1 holds, consider that along an equilibrium path the per capita output of region $\mathrm{j}$ is given by

$$
\frac{\mathrm{Y}_{\mathrm{jt}}}{\mathrm{P}_{\mathrm{jt}}}=\mathrm{b}_{\mathrm{jt}}\left\{\frac{\left[v\left(\mathrm{k}_{\mathrm{t}}, w\left(\mathrm{k}_{\mathrm{t}}, \mathrm{s}_{\mathrm{t}}, \mathrm{b}_{\mathrm{t}}\right)\right)\right]^{2}\left[\mu^{2}-\mu^{2}\left(1+\Omega \mathrm{s}_{\mathrm{t}}\right)^{2-\alpha}-\Omega^{2}\right]}{2 \mathrm{n} \alpha(1-\tau)^{2}(2-\alpha) \Omega^{2} \mathrm{k}_{\mathrm{t}}^{1-\alpha}}+\frac{\mathrm{n}\left(1+\Omega \mathrm{s}_{\mathrm{t}}\right)^{\alpha}}{2 \mathrm{k}_{\mathrm{t}}^{\alpha-1}}\right\}
$$

and the employment rate of region $\mathrm{j}$ is given by

$$
\frac{\mathrm{S}_{\mathrm{jt}}+\mathrm{A}_{\mathrm{jt}}}{\mathrm{P}_{\mathrm{jt}}}=\mathrm{b}_{\mathrm{jt}}\left[p\left(v\left(\mathrm{k}_{\mathrm{t}}, w\left(\mathrm{k}_{\mathrm{t}}, \mathrm{s}_{\mathrm{t}}, \mathrm{b}_{\mathrm{t}}\right)\right), \mathrm{k}_{\mathrm{t}}\right)+\mathrm{s}_{\mathrm{t}} q\left(v\left(\mathrm{k}_{\mathrm{t}}, w\left(\mathrm{k}_{\mathrm{t}}, \mathrm{s}_{\mathrm{t}}, \mathrm{b}_{\mathrm{t}}\right)\right), \mathrm{k}_{\mathrm{t}}, \mathrm{s}_{\mathrm{t}}\right)\right]
$$

where $b_{j t} \equiv \frac{M_{j t}}{P_{j t}}$ is the skilled labor-workers' population ratio of $j, j=1,2, . . J$.

This ratio evolves according to

$$
\mathrm{b}_{\mathrm{jt}+1}=\mathrm{b}_{\mathrm{jt}} \frac{\left[1+\rho\left(\mathrm{k}_{\mathrm{t}}, w\left(\mathrm{k}_{\mathrm{t}}, \mathrm{s}_{\mathrm{t}}, \mathrm{b}_{\mathrm{t}}\right), \mathrm{s}_{\mathrm{t}}\right)\right]}{(1-\sigma+\xi)}, \mathrm{b}_{\mathrm{j} 0} \text { given } \forall \mathrm{j},
$$


where $\mathrm{k}_{\mathrm{t}}, \mathrm{s}_{\mathrm{t}}$ and $\mathrm{b}_{\mathrm{t}}$ are governed by (19), (26) and (28). It is apparent that if $\mathrm{b}_{\mathrm{j} 0} \neq \mathrm{b}_{\mathrm{z} 0}, \mathrm{j} \neq \mathrm{z}$, then $\mathrm{b}_{\mathrm{jt}} \neq \mathrm{b}_{\mathrm{zt}} \forall \mathrm{t}$, entailing non convergence across regions in per capita output and employment rates.

\section{THE EQUILIBRIUM PATH WITHOUT INTERREGIONAL}

\section{REDISTRIBUTION}

The general equilibrium path under fiscal decentralization

Considering (13b) and (23), one has

$\mathrm{w}_{\mathrm{jt}}=\tau \mathrm{b}_{\mathrm{jt}}\left\{\frac{\left[\mu v\left(\mathrm{k}_{\mathrm{jt}}, \mathrm{w}_{\mathrm{jt}}\right)\right]^{2}\left[1-\left(1+\Omega \mathrm{s}_{\mathrm{jt}}\right)^{2-\alpha}\right]-\left[\Omega v\left(\mathrm{k}_{\mathrm{jt}}, \mathrm{w}_{\mathrm{jt}}\right)\right]^{2}}{2 \mathrm{n} \alpha(1-\tau)^{2}(2-\alpha) \Omega^{2} \mathrm{k}_{\mathrm{jt}}^{1-\alpha}}+\frac{\mathrm{nk}_{\mathrm{jt}}^{1-\alpha}\left(1+\Omega \mathrm{s}_{\mathrm{jt}}\right)^{\alpha}}{2}\right\}$.

Equation (31) allows to implicitly define $\mathrm{w}_{\mathrm{jt}}$ as a function of $\mathrm{k}_{\mathrm{jt}}, \mathrm{s}_{\mathrm{jt}}$ and $\mathrm{b}_{\mathrm{jt}}$ :

$$
\mathrm{w}_{\mathrm{jt}}=w\left(\mathrm{k}_{\mathrm{jt}}, \mathrm{s}_{\mathrm{jt}}, \mathrm{b}_{\mathrm{jt}}\right) \text {. }
$$

Moreover, the ratio $b_{j t}$ evolves according to

$$
\chi\left(\mathrm{b}_{\mathrm{jt}+1}, \mathrm{~b}_{\mathrm{jt}}, \mathrm{k}_{\mathrm{jt}}, \mathrm{w}_{\mathrm{jt}}, \mathrm{s}_{\mathrm{jt}}\right)=\mathrm{b}_{\mathrm{jt}+1}-\mathrm{b}_{\mathrm{jt}} \frac{\left[1+\rho\left(\mathrm{k}_{\mathrm{jt}}, \mathrm{w}_{\mathrm{jt}}, \mathrm{s}_{\mathrm{jt}}\right)\right]}{(1-\sigma+\xi)}=0, \mathrm{~b}_{\mathrm{j} 0} \text { given } \forall \mathrm{j},
$$

where $\rho($.$) is given by (22).$

One can use (21)-(22) to rewrite (20a) as 


$$
\frac{\left\{\sum_{\mathrm{j}=1}^{\mathrm{J}}\left[1+\rho\left(\mathrm{k}_{\mathrm{jt}}, \mathrm{w}_{\mathrm{jt}}, \mathrm{s}_{\mathrm{jt}}\right)\right] \mathrm{M}_{\mathrm{jt}} C\left(\mathrm{w}_{\mathrm{jt}+1}, \mathrm{k}_{\mathrm{jt}+1}, \mathrm{~s}_{\mathrm{jt}+1}, \mathrm{k}_{\mathrm{jt}+2}\right)\right\}^{\zeta}}{\left[\sum_{\mathrm{j}=1}^{\mathrm{J}} \mathrm{M}_{\mathrm{jt}} C\left(\mathrm{w}_{\mathrm{jt}}, \mathrm{k}_{\mathrm{jt}}, \mathrm{s}_{\mathrm{jt}}, \mathrm{k}_{\mathrm{jt}+1}\right)\right]^{\zeta}}=\theta\left(1+\mathrm{r}_{\mathrm{t}}\right) .
$$

Given equations (16), (17) and (34), the condition for equilibrium in the capital market becomes

$\Theta\left(\mathrm{k}_{1 \mathrm{t}+2}, \mathrm{~s}_{1 \mathrm{t}+1}, \mathrm{k}_{1 \mathrm{t}+1}, \mathrm{w}_{1 \mathrm{t}+1}, \mathrm{~s}_{1 \mathrm{t}}, \mathrm{k}_{1 \mathrm{t}}, \mathrm{w}_{1 \mathrm{t}}, \mathrm{M}_{1 \mathrm{t}}, \mathrm{k}_{2 \mathrm{t}+2}, \mathrm{~s}_{2 \mathrm{t}+1}, \mathrm{k}_{2 \mathrm{t}+1}, \mathrm{w}_{2 \mathrm{t}+1}, \mathrm{~s}_{2 \mathrm{t}}, \mathrm{k}_{2 \mathrm{t}}, \mathrm{w}_{2 \mathrm{t}}, \mathrm{M}_{2 \mathrm{t}}\right.$,

$$
\left.\mathrm{k}_{\mathrm{Jt}+2}, \mathrm{~s}_{\mathrm{Jt}+1}, \mathrm{k}_{\mathrm{Jt}+1}, \mathrm{w}_{\mathrm{Jt}+1}, \mathrm{~s}_{\mathrm{Jt}}, \mathrm{k}_{\mathrm{Jt}}, \mathrm{w}_{\mathrm{Jt}}, \mathrm{M}_{\mathrm{Jt}}\right)=0,
$$

where $\Theta()=.f\left(\mathrm{k}_{\mathrm{jt}+1}, \mathrm{~s}_{\mathrm{jt}+1}, v\left(\mathrm{k}_{\mathrm{jt}+1}, \mathrm{w}_{\mathrm{jt}+1}\right)\right)+1-\delta-$

$$
-\frac{\left\{\sum_{\mathrm{j}=1}^{\mathrm{J}}\left[1+\rho\left(\mathrm{k}_{\mathrm{jt}}, \mathrm{w}_{\mathrm{jt}}, \mathrm{s}_{\mathrm{jt}}\right)\right] \mathrm{M}_{\mathrm{jt}} C\left(\mathrm{w}_{\mathrm{jt}+1}, \mathrm{k}_{\mathrm{jt}+1}, \mathrm{~s}_{\mathrm{jt}+1}, \mathrm{k}_{\mathrm{jt}+2}\right)\right\}^{\zeta}}{\theta\left[\sum_{\mathrm{j}=1}^{\mathrm{J}} \mathrm{M}_{\mathrm{jt}} C\left(\mathrm{w}_{\mathrm{jt}}, \mathrm{k}_{\mathrm{jt}}, \mathrm{s}_{\mathrm{jt}}, \mathrm{k}_{\mathrm{jt}+1}\right)\right]^{\zeta}} \text { and } \mathrm{M}_{\mathrm{jt}} \text { evolves }
$$

according to (22).

One can use (32) to substitute for $\mathrm{w}_{\mathrm{jt}}$ in (19), (22), (33) and (35), thus obtaining the system of difference equations in $\mathrm{k}_{\mathrm{jt}}, \mathrm{s}_{\mathrm{jt}}$ and $\mathrm{b}_{\mathrm{jt}}$ and $\mathrm{M}_{\mathrm{jt}}$ that governs the general equilibrium path of the economy. 
The balanced growth path (BGP) under fiscal decentralization

Along a BGP, one must have $\mathrm{k}_{\mathrm{jt}+1}=\mathrm{k}_{\mathrm{jt}}=\mathrm{k}_{\mathrm{j}}, \mathrm{s}_{\mathrm{jt}+1}=\mathrm{s}_{\mathrm{jt}}=\mathrm{s}_{\mathrm{j}}$ and $\mathrm{b}_{\mathrm{jt}+1}=\mathrm{b}_{\mathrm{jt}}=\mathrm{b}_{\mathrm{j}}$ in (19), (22), (33) and (35). It is apparent by inspecting (33) that this entails $1+\rho\left(\mathrm{k}_{\mathrm{j}}, \mathrm{w}_{\mathrm{j}}, \mathrm{s}_{\mathrm{j}}\right)=1-\sigma+\xi$. Hence, along a BGP, equation (35) reduces to $f\left(\mathrm{k}_{\mathrm{j}}, \mathrm{s}_{\mathrm{j}}, v\left(\mathrm{k}_{\mathrm{j}}, w\left(\mathrm{k}_{\mathrm{j}}, \mathrm{s}_{\mathrm{j}}, \mathrm{b}_{\mathrm{j}}\right)\right)\right)+1-\delta=(1-\sigma+\xi) \zeta_{\theta^{-1}}$ and equation (22) can be rewritten as $\mathrm{M}_{\mathrm{jt}+1}=\mathrm{M}_{\mathrm{jt}}(1-\sigma+\xi)$. Therefore, a steady-state triple $\left(\mathrm{k}_{\mathrm{j}}, \mathrm{s}_{\mathrm{j}}, \mathrm{b}_{\mathrm{j}}\right)$ can be obtained by solving (19), (33) and (35) for $\mathrm{k}_{\mathrm{jt}+1}=\mathrm{k}_{\mathrm{jt}}=\mathrm{k}_{\mathrm{j}}, \mathrm{s}_{\mathrm{jt}+1}=\mathrm{s}_{\mathrm{jt}}=\mathrm{s}_{\mathrm{j}}$ and $\mathrm{b}_{\mathrm{jt}+1}=\mathrm{b}_{\mathrm{jt}}=\mathrm{b}_{\mathrm{j}}$. Thus, the following proposition holds:

Proposition 2 In the absence of interregional redistribution (fiscal decentralization), structurally similar regions are characterized by the same steady-state levels of per capita output and employment rate.

To verify that Proposition 2 holds, consider that along a BGP the per capita output of region $\mathrm{j}$ is given by

$$
\frac{\mathrm{Y}_{\mathrm{jt}}}{\mathrm{P}_{\mathrm{jt}}}=\mathrm{b}_{\mathrm{j}}\left\{\frac{\left[v\left(\mathrm{k}_{\mathrm{j}}, w\left(\mathrm{k}_{\mathrm{j}}, \mathrm{s}_{\mathrm{j}}, \mathrm{b}_{\mathrm{j}}\right)\right)\right]^{2}\left[\mu^{2}-\mu^{2}\left(1+\Omega \mathrm{s}_{\mathrm{j}}\right)^{2-\alpha}-\Omega^{2}\right]}{2 \mathrm{n} \alpha(1-\tau)^{2}(2-\alpha) \Omega^{2} \mathrm{k}_{\mathrm{j}}^{1-\alpha}}+\frac{\mathrm{n}\left(1+\Omega \mathrm{s}_{\mathrm{j}}\right)^{\alpha}}{2 \mathrm{k}_{\mathrm{j}}^{\alpha-1}}\right\}
$$

and the employment rate of region $\mathrm{j}$ is given by 


$$
\frac{\mathrm{S}_{\mathrm{jt}}+\mathrm{A}_{\mathrm{jt}}}{\mathrm{P}_{\mathrm{jt}}}=\mathrm{b}_{\mathrm{j}}\left[p\left(v\left(\mathrm{k}_{\mathrm{j}}, w\left(\mathrm{k}_{\mathrm{j}}, \mathrm{s}_{\mathrm{j}}, \mathrm{b}_{\mathrm{j}}\right)\right), \mathrm{k}_{\mathrm{j}}\right)+\mathrm{s}_{\mathrm{j}} q\left(v\left(\mathrm{k}_{\mathrm{j}}, w\left(\mathrm{k}_{\mathrm{j}}, \mathrm{s}_{\mathrm{j}}, \mathrm{b}_{\mathrm{j}}\right)\right), \mathrm{k}_{\mathrm{j}}, \mathrm{s}_{\mathrm{j}}\right)\right] .
$$

Noting that the steady-state levels of per capita output and employment rate in region $\mathrm{j}$ depend only on the steady-state triple $\left(\mathrm{k}_{\mathrm{j}}, \mathrm{s}_{\mathrm{j}}, \mathrm{b}_{\mathrm{j}}\right)$, which in its turn depends only on the parameter values (that are assumed to be equal across regions), it is apparent that Proposition 2 holds.

Moreover, it is worth to note that if there is more than one steady-state triple $\left(\mathrm{k}_{\mathrm{j}}, \mathrm{s}_{\mathrm{j}}, \mathrm{b}_{\mathrm{j}}\right)$ satisfying (19), (33) and (35) for $\mathrm{k}_{\mathrm{jt}+1}=\mathrm{k}_{\mathrm{jt}}=\mathrm{k}_{\mathrm{j}}, \mathrm{s}_{\mathrm{jt}+1}=\mathrm{s}_{\mathrm{jt}}=\mathrm{s}_{\mathrm{j}}$ and $\mathrm{b}_{\mathrm{jt}+1}=\mathrm{b}_{\mathrm{jt}}=\mathrm{b}_{\mathrm{j}}$, then along a BGP structurally similar regions may exhibit different per capita output and employment rate. Conversely, the existence of a unique $\left(\mathrm{k}_{\mathrm{j}}, \mathrm{s}_{\mathrm{j}}, \mathrm{b}_{\mathrm{j}}\right)$ implies that along a BGP structurally similar regions must necessarily exhibit the same per capita output and employment rate. Considering parameter values that rule out the possibility of multiple $\left(\mathrm{k}_{\mathrm{j}}, \mathrm{s}_{\mathrm{j}}, \mathrm{b}_{\mathrm{j}}\right)$, one can produce numerical examples showing that the system obtained by linearizing the difference equations governing the equilibrium path of the regional economies around its (unique) BGP exhibits saddle-path stability (see 
the Appendix). This implies that for these parameter values the following proposition holds:

Proposition 3 In the absence of interregional redistribution (fiscal decentralization), structurally similar regions whose initial per capita output and employment rate are not too far away from their steady-state values converge to the same per capita output and employment rate.

This proposition is a consequence of the fact that along a BGP structurally similar regions have the same per capita output and employment rate, together with the fact that in a neighborhood of the BGP the linear approximation of the system governing the equilibrium path of the economy is saddle-path stable.

\section{CONCLUSIONS}

This paper shows that a system of centralized income redistribution can perpetuate the differentials in output per capita and employment rate across regions. This is because redistributive programs providing equal transfer payments and welfare entitlements to households living in areas that differ in GDP per head and productivity levels tend to equalize the non-labor income of 
the workers, thus influencing the process of wage determination. Indeed, in the presence of interregional redistribution, the wages cannot fully reflect the differences in per capita productivity among the different areas, even if the wage-setting process is decentralized. In this respect, an implication of the paper is that decentralized wage determination is not sufficient to insure convergence in per capita output and employment rate across regions. It would be also possible to show that even with competitive labor markets the combination of labor immobility and centralized income redistribution prevents the interregional differentials to vanish in time. ${ }^{17}$ Especially for Europe, where it is not realistic to expect a resumption of significant interregional labor flows, this conclusion may support the argument that both at national levels and at the level of the European Union there is a trade off between social policies aimed at providing all citizens with the same basic entitlements and the elimination of regional disparities in GDP per head and employment rate.

\footnotetext{
${ }^{17}$ See Bonatti (1999). In other words -- differently than in Perotti (2001) - the existence of
} 


\section{APPENDIX}

\section{Derivation of the firms' (gross) profit function $\pi^{\mathrm{g}}($.}

Given the perfectly transferable nature of the general skills acquired by an apprentice, each employer is aware that there is no guarantee that a newly hired worker will remain with his/her firm in the future. This is why an employer does not consider the future returns accruing from the on-the-job training of an apprentice: since the forthcoming benefit of adding a skilled worker to the stock of human capital available to the economy as a whole cannot be appropriated privately, the employer can ignore it as an insignificant externality. Therefore, the selection of the optimal labor policies by a firm amounts in each $t$ to solving the static decision problem of maximizing (3) with respect to $S_{j i t}$ and $A_{\text {jit }}$. Given its optimal labor policies, a firm is able to determine at the beginning of $\mathrm{t}$ the amount of $\mathrm{K}_{\mathrm{jit}}$ to borrow and install. As the local shock is favorable, the aggregate demand for either trained labor or apprentices by firms in location i may be rationed. In the aggregate, it is always the case that:

$$
\begin{aligned}
& S_{\text {jit }} \leq M_{\text {jit }}, \\
& A_{\text {jit }} \leq L_{\text {jit }} .
\end{aligned}
$$

When labor demand happens to be rationed, it is reasonable to assume that the scarce supply of labor is evenly distributed among firms of the same location. Note that the union wages are not determined at the firm level and that employers cannot compete for labor in short supply by raising the relevant

noncompetitive labor markets is not essential in this model. 
wages in order to keep and poach workers, even if skills are perfectly transferable among firms (see Soskice, 1990). Therefore, with one as the normalized number of firms of location i, we can take (A1) to be the constraints faced by each individual firm as the union wages induce all the available skilled and trainable workers to accept a job offer. Hence, the firm' s choice of the labor inputs amounts to solving the static decision problem of maximizing (3) subject to (2) and (A1), from which one can derive the optimal labor policies:

$$
\mathrm{S}_{\mathrm{jit}}=S\left(\mathrm{x}_{\mathrm{it}}, \mathrm{M}_{\mathrm{jit}}, \mathrm{k}_{\mathrm{jit}}, \mathrm{v}_{\mathrm{jit}}\right)=\left\{\begin{array}{l}
\mathrm{M}_{\mathrm{jit}} \mathrm{k}_{\mathrm{jit}}\left[\frac{(1-\tau) \alpha \mathrm{x}_{\mathrm{it}}}{\mathrm{v}_{\mathrm{jit}}}\right]^{1 /(1-\alpha)} \text { if } \mathrm{x}_{\mathrm{it}} \leq \frac{\mathrm{v}_{\mathrm{jit}} \mathrm{k}_{\mathrm{jit}}^{\alpha-1}}{(1-\tau) \alpha}, \mathrm{k}_{\mathrm{jit}} \equiv \frac{\mathrm{K}_{\mathrm{jit}}}{\mathrm{M}_{\mathrm{jit}}}(\mathrm{A} 2 \mathrm{a}) \\
\mathrm{M}_{\mathrm{jit}} \text { otherwise, }
\end{array}\right.
$$

$$
\mathrm{A}_{\mathrm{jit}}=A\left(\mathrm{x}_{\mathrm{it}}, \mathrm{M}_{\mathrm{jit}}, \mathrm{k}_{\mathrm{jit}} \mathrm{s}_{\mathrm{jit}}, \mathrm{v}_{\mathrm{jit}}\right)=\left\{\begin{array}{l}
0 \text { if } \mathrm{x}_{\mathrm{it}} \leq \frac{\mu v_{\mathrm{jit}} \mathrm{x}_{\mathrm{jit}}^{\alpha-1}}{(1-\tau) \sigma \Omega} \\
\mathrm{M}_{\mathrm{jit}} \mathrm{s}_{\mathrm{jit}} \text { if } \mathrm{x}_{\mathrm{it}}>\frac{\mu \mathrm{v}_{\mathrm{jit}}\left(1+\Omega \mathrm{s}_{\mathrm{jit}}\right) \mathrm{k}_{\mathrm{jit}}^{\alpha-1}}{(1-\tau) \alpha \Omega}, \mathrm{s}_{\mathrm{jit}} \equiv \frac{\mathrm{L}_{\mathrm{jit}}}{\mathrm{M}_{\mathrm{jit}}} \\
\mathrm{M}_{\mathrm{jit}} \mathrm{k}_{\mathrm{jit}}\left[\frac{(1-\tau) O \mathrm{x}_{\mathrm{it}}}{\Omega^{-\alpha} \mu \mathrm{v}_{\mathrm{jit}}}\right]^{1 / 1(1-\alpha)}-\frac{\mathrm{M}_{\mathrm{jit}}}{\Omega} \text { otherwise. }
\end{array}\right.
$$

The firms' $n$ et profits are an increasing function of In fact, using (2), (3) and (A2), one has:

$$
\pi^{\mathrm{g}}=\pi\left(\mathrm{M}_{\mathrm{jit}}, \mathrm{k}_{\mathrm{jit}}, \mathrm{S}_{\mathrm{jit}}, \mathrm{v}_{\mathrm{jit}}, \mathrm{x}_{\mathrm{it}}\right)
$$

where 


$$
\pi(.)=\left\{\begin{array}{l}
(1-\alpha) \mathrm{M}_{\mathrm{jit}} \mathrm{k}_{\mathrm{jit}}\left[\left(\frac{\alpha}{\mathrm{v}_{\mathrm{jit}}}\right)^{\alpha}(1-\tau) \mathrm{x}_{\mathrm{itt}}\right]^{1 /(1-\alpha)} \text { if } \mathrm{x}_{\mathrm{it}} \leq \frac{\mathrm{v}_{\mathrm{jit}} \mathrm{k}_{\mathrm{jit}}^{\alpha-1}}{(1-\tau) \alpha} \\
(1-\tau) \mathrm{x}_{\mathrm{it}} \mathrm{M}_{\mathrm{jit}} \mathrm{k}_{\mathrm{jit}}^{1-\alpha}-\mathrm{M}_{\mathrm{jit}} \mathrm{v}_{\mathrm{jit}} \text { if } \frac{\mathrm{v}_{\mathrm{jit}} \mathrm{k}_{\mathrm{jit}}^{\alpha-1}}{(1-\tau) \alpha}<\mathrm{x}_{\mathrm{it}} \leq \frac{\mu \mathrm{v}_{\mathrm{jit}} \mathrm{k}_{\mathrm{jit}}^{\alpha-1}}{(1-\tau) \alpha \Omega} \\
(1-\tau) \mathrm{x}_{\mathrm{it}} \mathrm{M}_{\mathrm{jit}} \mathrm{k}_{\mathrm{jit}}^{1-\alpha}\left(1+\Omega \mathrm{s}_{\mathrm{jit}}\right)^{\alpha}-\mathrm{M}_{\mathrm{jit}} \mathrm{v}_{\mathrm{jit}}-\mathrm{s}_{\mathrm{jit}} \mathrm{M}_{\mathrm{jit}} \mu \mathrm{v}_{\mathrm{jit}} \text { if } \mathrm{x}_{\mathrm{it}}>\frac{\mu \mathrm{v}_{\mathrm{jit}}\left(1+\Omega \mathrm{s}_{\mathrm{jit}}\right)^{1-\alpha}}{(1-\tau) \alpha \Omega \mathrm{k}_{\mathrm{jit}}^{1-\alpha}} \\
(1-\alpha) \mathrm{M}_{\mathrm{jit}} \mathrm{k}_{\mathrm{jit}}\left[\left(\frac{\alpha \Omega}{\mu \mathrm{v}_{\mathrm{jit}}}\right)^{\alpha}(1-\tau) \mathrm{x}_{\mathrm{it}}\right]^{1 /(1-\alpha)}+\frac{(\mu-\Omega) \mathrm{M}_{\mathrm{jit}} \mathrm{v}_{\mathrm{jit}}}{\Omega} \text { otherwise. }
\end{array}\right.
$$

\section{Derivation of the equilibrium condition for the trainable labor market and of}

the wage rule

Having the optimal demand for skilled labor in (A2a), one can compute the probability of a skilled worker located in $\mathrm{i}$ (before the realization of $\mathrm{x}_{\mathrm{it}}$ ) to be employed in period $t$ :

$$
p\left(\mathrm{v}_{\mathrm{jit}}, \mathrm{k}_{\mathrm{jit}}\right)=1-\frac{\mathrm{v}_{\mathrm{jit}} \mathrm{k}_{\mathrm{jit}}^{\alpha-1}}{\mathrm{n} \alpha(1-\tau)(2-\alpha)}, p_{\mathrm{v}}<0, p_{\mathrm{k}}>0 .
$$

By using (6) and (A4), one can write the period utility expected (before the realization of $\mathrm{x}_{\mathrm{it}}$ ) by a skilled worker located in $\mathrm{i}$ :

$u^{\mathrm{sk}}\left(\mathrm{v}_{\mathrm{jit}}, \mathrm{k}_{\mathrm{jit}}, \mathrm{w}_{\mathrm{jt}}\right)=\left[1-\frac{\mathrm{v}_{\mathrm{jit}} \mathrm{k}_{\mathrm{jit}}^{\alpha-1}}{\mathrm{n} \alpha(1-\tau)(2-\alpha)}\right] u\left(\mathrm{w}_{\mathrm{jt}}+\mathrm{v}_{\mathrm{jit}}\right)+\frac{\mathrm{v}_{\mathrm{jit}} \mathrm{k}_{\mathrm{jit}}^{\alpha-1}}{\mathrm{n} \alpha(1-\tau)(2-\alpha)} u\left(\eta_{\mathrm{w}_{\mathrm{jt}}}\right)$. 
Similarly, one can use (A2b) to compute the probability that a trainable worker located in $\mathrm{i}$ (before the realization of $\mathrm{x}_{\mathrm{it}}$ ) will be hired in period $\mathrm{t}$ :

$$
q\left(\mathrm{v}_{\mathrm{jit}}, \mathrm{k}_{\mathrm{jit}}, \mathrm{s}_{\mathrm{jit}}\right)=1-\frac{\mu \mathrm{v}_{\mathrm{jit}} \mathrm{k}_{\mathrm{jit}}^{\alpha-1}\left[\left(1+\Omega \mathrm{s}_{\mathrm{jit}}\right)^{2-\alpha}-1\right]}{\mathrm{n} \alpha(1-\tau)(2-\alpha) \Omega^{2} \mathrm{~s}_{\mathrm{jit}}}, q_{\mathrm{v}}<0, q_{\mathrm{k}}>0, q_{\mathrm{s}}<0 .
$$

Note that $q($.$) diminishes as there is a larger number of trainable workers,$ remaining constant both the size of the skilled workforce and the stock of capital located in i. In equilibrium, the number of unskilled workers who become trainable in location $\mathrm{i}$ must be such that an unskilled worker is indifferent between investing in basic knowledge or staying in the informal economy:

$$
h(\mathrm{c})=q\left(\mathrm{v}_{\mathrm{jit}}, \mathrm{k}_{\mathrm{jit}}, \mathrm{s}_{\mathrm{jit}}\right)\left[u\left(\mathrm{w}_{\mathrm{jt}}+\mu \mathrm{v}_{\mathrm{jit}}\right)-u\left(\eta_{\mathrm{jt}}\right)+\phi\left(\mathrm{U}_{\mathrm{jt}+1}^{\mathrm{sk}}-\mathrm{U}_{\mathrm{jt}+1}^{\mathrm{un}}\right)\right],
$$

where along an equilibrium path

$$
\mathrm{U}_{\mathrm{jt}}^{\mathrm{un}}=u\left(\eta \mathrm{w}_{\mathrm{jt}}\right)+\phi \mathrm{U}_{\mathrm{jt}+1}^{\mathrm{un}} .
$$

The period utility function of a skilled worker depends on the real wage, on the government transfers and on the physical capital/skilled labor ratio, which is a predetermined variable when an union sets the wage. Given the forward looking behavior of firms and unskilled workers, the current wage policy of an union could affect the union's future policy and the utility of its members only if it had a significant impact on the investors' behavior and on the future income transfers in favor of the workers. However, this is not the case because of the 
continuum of unions operating in each region. Thus, the problem of a single union amounts to solve the following sequence of static problems:

$$
\max _{\mathrm{v}_{\mathrm{jit}}} u^{\mathrm{sk}}\left(\mathrm{v}_{\mathrm{jit}}, \mathrm{k}_{\mathrm{jit}}, \mathrm{w}_{\mathrm{jt}}\right) \text {, }
$$

from which one obtains the following sequence of first-order conditions:

$$
\frac{\partial u^{\mathrm{sk}}\left(\mathrm{v}_{\mathrm{jit}}, \mathrm{k}_{\mathrm{jit}}, \mathrm{w}_{\mathrm{jt}}\right)}{\partial \mathrm{v}_{\mathrm{jit}}}=0,
$$

defining implicitly the time-invariant wage rule (17).

\section{Uniqueness and local stability of the BGP under fiscal decentralization}

From the fact that along a BGP one has $1+\rho\left(\mathrm{k}_{\mathrm{j}}, \mathrm{w}_{\mathrm{j}}, \mathrm{s}_{\mathrm{j}}\right)=1-\sigma+\xi$, one can derive from (22) and (A6) the following two equations that must be satisfied along a BGP:

$$
\begin{gathered}
q\left(\mathrm{v}_{\mathrm{j}}, \mathrm{k}_{\mathrm{j}}, \mathrm{s}_{\mathrm{j}}\right)=\xi\left[\mathrm{s}_{\mathrm{j}}(1-\sigma)\right]^{-1}, \quad \xi(1-\sigma)^{-1} \leq \mathrm{s}_{\mathrm{j}} \leq \overline{\mathrm{s}}_{\mathrm{j}} \\
\mathrm{v}_{\mathrm{j}}=\mathrm{n}(2-\alpha) \alpha(1-\tau) \mathrm{k}_{\mathrm{j}}^{1-\alpha} z\left(\mathrm{~s}_{\mathrm{j}}\right), z\left(\mathrm{~s}_{\mathrm{j}}\right)=\frac{\left[\mathrm{s}_{\mathrm{j}}-\xi(1-\sigma)^{-1}\right] \Omega^{2}}{\mu\left[\left(1+\Omega \mathrm{s}_{\mathrm{j}}\right)^{2-\alpha}-1\right]}, \xi(1-\sigma)^{-1} \leq \mathrm{s}_{\mathrm{j}} \leq \overline{\mathrm{s}}_{\mathrm{j}}
\end{gathered}
$$

where $\bar{s}_{j}$ is that value of $s_{j}$ above which in no location and in no period one may have shortage of trainable labor. ${ }^{18}$

\footnotetext{
${ }^{18}$ Thus, $\bar{s}_{\mathrm{j}}$ is that value of $\mathrm{s}_{\mathrm{j}}$ satisfying $\left(1+\Omega \mathrm{s}_{\mathrm{j}}\right)^{1-\alpha}\left[\mathrm{s}_{\mathrm{j}}-\xi(1-\sigma)^{-1}\right](2-\alpha) \Omega=\left[\left(1+\Omega \mathrm{s}_{\mathrm{j}}\right)^{2-\alpha}-1\right]$.
} 
By specifying a CRRA utility function for the workers $\left[u()=.\frac{(.)^{1-\varphi}}{1-\varphi}, \varphi \geq 0\right]$, equations (A9) and (A11) allow to determine the steady-state value of $\mathrm{w}_{\mathrm{jt}}$ as a function of $\mathrm{k}_{\mathrm{j}}$ and $\mathrm{s}_{\mathrm{j}}$ :

$$
\mathrm{w}_{\mathrm{j}}=\mathrm{n}(2-\alpha) \alpha(1-\tau) \mathrm{k}_{\mathrm{j}}^{1-\alpha} g\left(\mathrm{~s}_{\mathrm{j}}\right), g^{\prime}>0, \underline{\mathrm{s}}_{\mathrm{j}} \leq \mathrm{s}_{\mathrm{j}} \leq \overline{\mathrm{s}}_{\mathrm{j}},
$$

where $\underline{s}_{j}>\xi(1-\sigma)^{-1}$ is that value of $s_{j}$ at which $g\left(s_{j}\right)=0 .{ }^{19}$

Since along a BGP (35) reduces to

$$
f\left(\mathrm{k}_{\mathrm{j}}, \mathrm{s}_{\mathrm{j}}, \mathrm{v}_{\mathrm{j}}\right)=\delta-1+(1-\sigma+\xi) \zeta_{\theta^{-1}},
$$

one can use (16) and (A11) to rewrite (A13) as $\mathrm{k}_{\mathrm{j}}=\Gamma\left(\mathrm{s}_{\mathrm{j}}\right)$, where

$$
\Gamma(.)=\left\{\frac{\mathrm{n}(1-\alpha)(1-\tau)}{2\left[\delta-1+(1-\sigma+\xi)^{\zeta} \theta^{-1}\right]}\right\}^{1 / \alpha}\left\{\frac{(2-\alpha) \alpha \Omega^{2}\left[1-\left(1+\Omega \mathrm{s}_{\mathrm{j}}\right)^{2-\alpha}-\left(\frac{\Omega}{\mu}\right)^{2}\right]}{\left[\mathrm{s}_{\mathrm{j}}-\xi(1-\sigma)^{-1}\right]^{-2}\left[\left(1+\Omega \mathrm{s}_{\mathrm{j}}\right)^{2-\alpha}-1\right]^{2}}+\left(1+\Omega \mathrm{s}_{\mathrm{j}}\right)^{\alpha}\right\}^{1 / \alpha},
$$

Similarly, since along a BGP (19) reduces to

$$
\frac{(1-\phi) h(\mathrm{c})}{q\left(\mathrm{v}_{\mathrm{j}}, \mathrm{k}_{\mathrm{j}}, \mathrm{s}_{\mathrm{j}}\right)}=u\left(\mathrm{w}_{\mathrm{j}}+\mu \mathrm{v}_{\mathrm{j}}\right)(1-\phi)-u\left(\eta \mathrm{w}_{\mathrm{j}}\right)+\phi u^{\mathrm{sk}}\left(\mathrm{v}_{\mathrm{j}}, \mathrm{k}_{\mathrm{t}}, \mathrm{w}_{\mathrm{j}}\right)
$$

${ }^{19}$ For instance, if $\varphi=0$, then $\mathrm{g}\left(\mathrm{s}_{\mathrm{j}}\right)=\frac{2\left[\mathrm{~s}_{\mathrm{j}}-\xi(1-\sigma)^{-1}\right] \Omega^{2}}{(\eta-1) \mu\left[\left(1+\Omega \mathrm{s}_{\mathrm{j}}\right)^{2-\alpha}-1\right]}-\frac{1}{(\eta-1)}$ and $\underline{\mathrm{s}}_{\mathrm{j}}$ is that value of $\mathrm{s}_{\mathrm{j}}$ satisfying $2\left[\mathrm{~s}_{\mathrm{j}}-\xi(1-\sigma)^{-1}\right] \Omega^{2}=\mu\left[\left(1+\Omega \mathrm{s}_{\mathrm{j}}\right)^{2-\alpha}-1\right]$. 
one can use (A10), (A11) and (A12) to rewrite (A15) as $\mathrm{k}_{\mathrm{j}}=\Lambda\left(\mathrm{s}_{\mathrm{j}}\right)$, where

$$
\Lambda(.)=\left\{\begin{array}{c}
\left.\frac{[\mathrm{n} \alpha(2-\alpha)(1-\tau)]^{\varphi-1}(1-\phi) h(\mathrm{c})(1-\sigma)(1-\varphi) \xi^{-1}}{(1-\phi)\left[g\left(\mathrm{~s}_{\mathrm{j}}\right)+\mu z\left(\mathrm{~s}_{\mathrm{j}}\right)\right]^{1-\varphi}-\left[\eta g\left(\mathrm{~s}_{\mathrm{j}}\right)\right]^{1-\varphi}+\phi\left[1-z\left(\mathrm{~s}_{\mathrm{j}}\right)\right]\left[g\left(\mathrm{~s}_{\mathrm{j}}\right)+z\left(\mathrm{~s}_{\mathrm{j}}\right)\right]^{1-\varphi}+\phi z\left(\mathrm{~s}_{\mathrm{j}}\right)\left[\eta g\left(\mathrm{~s}_{\mathrm{j}}\right)\right]^{1-\varphi}}\right\}^{1 /(1-\alpha)(1-\varphi)}, \\
\underline{\mathrm{s}}_{\mathrm{j}} \leq \mathrm{s}_{\mathrm{j}} \leq \overline{\mathrm{s}}_{\mathrm{j}} . \quad \text { (A16) }
\end{array}\right.
$$

Along a BGP one must have $\Gamma\left(\mathrm{s}_{\mathrm{j}}\right)=\Lambda\left(\mathrm{s}_{\mathrm{j}}\right)$. A sufficient condition for having a unique BGP is that $\Gamma^{\prime} \leq 0$ and $\Lambda^{\prime}>0, \underline{s}_{j} \leq s_{j} \leq \bar{s}_{j}$. As a numerical example, let $\zeta=\varphi=0, \quad \xi=\sigma=0.05, \mu=0.52, \Omega=0.5, \eta=1.25, \tau=0.4, \delta=0.1, \phi=\theta=0.9, \alpha=2 / 3$, $h(\mathrm{c})=0.1949722$ and $\mathrm{n}=1$. One can check that with these parameter values $\Gamma^{\prime} \leq 0$ and $\quad \Lambda^{\prime}>0, \quad \underline{\mathrm{s}}_{\mathrm{j}}=0.1774441 \leq \mathrm{s}_{\mathrm{j}} \leq \overline{\mathrm{s}}_{\mathrm{j}}=0.92405$. Moreover, given these parameter values, the unique BGP is characterized by $\mathrm{s}_{\mathrm{j}}^{*}=0.2$, $\mathrm{k}_{\mathrm{j}}^{*}=0.2276078, \mathrm{~b}_{\mathrm{j}}^{*}=0.61936, \mathrm{v}_{\mathrm{j}}^{*}=0.1702564$ and $\mathrm{w}_{\mathrm{j}}^{*}=0.0595213$.

To check that these parameter values are consistent with the saddle-path stability of the system obtained by linearizing the difference equations that govern the motion of the economy in a neighborhood of its BGP, one should note that with $\zeta=0$ the equilibrium path can be characterized by two difference equations in $\mathrm{k}_{\mathrm{jt}}$ and $\mathrm{s}_{\mathrm{jt}}$. Indeed, with $\zeta=0$ equation (35) reduces to

$$
f(.)=\frac{(1-\alpha) \mathrm{v}_{\mathrm{jt}}^{2}\left\{(\mu / \Omega)^{2}\left[1-\left(1+\Omega \mathrm{s}_{\mathrm{jt}}\right)^{2-\alpha}\right]-1\right\}}{2 \mathrm{n} \alpha(2-\alpha)(1-\tau) \mathrm{k}_{\mathrm{jt}}^{2-\alpha}}+\frac{(1-\alpha)(1-\tau) \mathrm{n}}{2\left(1+\Omega \mathrm{s}_{\mathrm{jt}}\right)^{-\alpha} \mathrm{k}_{\mathrm{jt}}^{\alpha}}=\delta+\theta^{-1}-1 .
$$

Moreover, since with $\varphi=0$ the wage rule (17) is 


$$
\mathrm{v}_{\mathrm{jt}}=v\left(\mathrm{k}_{\mathrm{jt}}, \mathrm{w}_{\mathrm{jt}}\right)=\frac{\mathrm{n} \alpha(2-\alpha)(1-\tau) \mathrm{k}_{\mathrm{jt}}^{1-\alpha}+(\eta-1) \mathrm{w}_{\mathrm{jt}}}{2},
$$

one can use (A17) and (A18) to write $\mathrm{w}_{\mathrm{jt}}$ as a function of $\mathrm{k}_{\mathrm{jt}}$ and $\mathrm{s}_{\mathrm{jt}}$ :

$$
\mathrm{w}_{\mathrm{jt}}=\varsigma\left(\mathrm{k}_{\mathrm{jt}}, \mathrm{s}_{\mathrm{jt}}\right)
$$

where

$$
\varsigma(.)=\frac{\mathrm{n} \alpha(2-\alpha)(1-\tau)}{(1-\eta) \mathrm{k}_{\mathrm{jt}}^{\alpha-1}}+\left\{\frac{4 \mathrm{n} \alpha(2-\alpha)(1-\tau)\left[2\left(\delta+\theta^{-1}-1\right)-\mathrm{n}(1-\alpha)\left(1+\Omega \mathrm{s}_{\mathrm{jt}}\right)^{\alpha} \mathrm{k}_{\mathrm{jt}}(1-\tau)\right]}{\mathrm{k}_{\mathrm{jt}}^{\alpha-2}(\eta-1)^{2}(1-\alpha)\left\{(\mu / \Omega)^{2}\left[1-\left(1+\Omega \mathrm{s}_{\mathrm{jt}}\right)^{2-\alpha}\right]-1\right\}}\right\}^{1 / 2} .
$$

Finally, considering (31), one can use (A17) and (A19) to write $b_{j t}$ as a function of $\mathrm{k}_{\mathrm{jt}}$ and $\mathrm{s}_{\mathrm{jt}}$ :

$$
\mathrm{b}_{\mathrm{jt}}=b\left(\mathrm{k}_{\mathrm{jt}}, \mathrm{s}_{\mathrm{jt}}\right)=\frac{\varsigma\left(\mathrm{k}_{\mathrm{jt}}, \mathrm{s}_{\mathrm{jt}}\right)(1-\alpha)(1-\tau)}{\tau \mathrm{k}_{\mathrm{jt}}\left(\delta+\theta^{-1}-1\right)} .
$$

Given (A19) and (A20), the economy of each region is governed by the following system of difference equations in $\mathrm{k}_{\mathrm{jt}}$ and $\mathrm{s}_{\mathrm{jt}}$ :

$$
\begin{gathered}
\Psi\left(\mathrm{s}_{\mathrm{jt}+1}, \mathrm{k}_{\mathrm{jt}+1}, \varsigma\left(\mathrm{k}_{\mathrm{jt}+1}, \mathrm{~s}_{\mathrm{jt}+1}\right), \mathrm{s}_{\mathrm{jt}}, \mathrm{k}_{\mathrm{jt}}, \varsigma\left(\mathrm{k}_{\mathrm{jt}}, \mathrm{s}_{\mathrm{jt}}\right)\right)=0, \\
\chi\left(b\left(\mathrm{k}_{\mathrm{jt}+1}, \mathrm{~s}_{\mathrm{jt}+1}\right), b\left(\mathrm{k}_{\mathrm{jt}}, \mathrm{s}_{\mathrm{jt}}\right), \mathrm{k}_{\mathrm{jt}}, \varsigma\left(\mathrm{k}_{\mathrm{jt}}, \mathrm{s}_{\mathrm{jt}}\right), \mathrm{s}_{\mathrm{jt}}\right)=0,
\end{gathered}
$$

where $\Psi($.$) and \chi($.$) are given, respectively, by (19) and (33).$

Linearizing (A21)-(A22) around $\left(\mathrm{s}_{\mathrm{j}}^{*}=0.2, \mathrm{k}_{\mathrm{j}}^{*}=0.2276078\right)$, one can derive the following characteristic equation of the linearized system: 
$\lambda^{2}-1.9511209 \lambda+0.925374=0$, where $\lambda_{1}=1.1378687$ and $\lambda_{2}=0.8132522$ are the solving characteristic roots, implying saddle-path stability.

\section{REFERENCES}

Acemoglu, D. (1996), A Microfoundation for Social Increasing Returns in Human Capital, Quaterly Journal of Economics 111, 779-804.

Barro, R.J. and Sala-i-Martin, X. (1995), Economic Growth, New York: McGraw-Hill.

Bertola, G. (2001), Taxes and Social Policy in the European Union: Trilemmas and Labour Market Implications, in M. Bordignon and D. da Empoli (eds.), Politica fiscale, flessibilità dei mercati e crescita, Milano: Franco Angeli.

Blanchard, O.J. and Katz, L.F. (1997), Regional Evolutions, Brookings Papers on Economic Activity, No.1, 1-61.

Blanchflower, D. and Oswald, A. (1994), The Wage Curve, Cambridge Mass.: MIT Press. 
Boldrin, M. and Canova, F. (2001), Inequality and convergence in Europe's regions: reconsidering European regional policies, Economic Policy, 207-253.

Boltho, A., Carlin, W. and Scaramozzino, P. (1997), Will East Germany Become a New Mezzogiorno?, Journal of Comparative Economics 24, 241264.

Bonatti, L. (1999), 'Growth, real interest, employment and wage determination”, Discussion Paper No. 5, Dipartimento di Economia, Universitá di Trento.

Burdett, K. and Smith, E. (1995), The Low-Skill Trap, Discussion Paper No. 95-40, Department of Economics, University of British Columbia.

Caniëls, M., Fagerberg, J. and Verspagen, B. (1997), Technology, growth and unemployment across European regions, Regional Studies 31, No. 5, 457-66.

Decressin, J. and Fatás, A. (1995), Regional labor dynamics in Europe, European Economic Review 39, 1627-55. 
De Long, J.B. and Summers, L.H. (1992), Equipment Investment and Economic Growth: How Strong is the Nexus?, Brookings Papers on Economic Activity, No.2, 157-211.

European Commission (1999), Employment in Europe 1999, Brussels: Commission of the European Communities.

Fagerberg, J. and Verspagen, B. (1996), Heading for Divergence? Regional growth in Europe reconsidered, Journal of Common Market Studies 34, 431-48.

Faini, R. (1999), Trade unions and regional development, European Economic Review 43, 457-474.

Haskel, J. and Martin, C. (1996), Skill Shortages, Productivity Growth and Wage Inflation, in A.L. Booth and D.J. Snower (eds.), Acquiring Skills, Cambridge: Cambridge University Press.

Neven, D. and Gouyette, C. (1995), Regional Convergence in the European Community, Journal of Common Market Studies 33, 47-65.

Obstfeld, M. and Peri, G. (1998), Regional non-adjustment and fiscal policy, Economic Policy, 207-259. 
OECD (1991), Employment Outlook 1991, Paris: OECD Publications.

Perotti, R. (2001), Is a Uniform Social Policy Better? Fiscal Federalism and Factor Mobility, American Economic Review 91, 596-610.

Phelps, E.S. (1997), Rewarding Work, Cambridge Mass.: Harvard University Press.

Pissarides, C.A. (1998), The impact of employment tax cuts on unemployment and wages; the role of unemployment benefits and tax structure, European Economic Review 42, 155-83.

Redding, S. (1996), The Low-Skill, Low-Quality Trap: Strategic Complementarities between Human Capital and R\&D, Economic Journal 106, 458-470.

Sinn, H-W. and Westermann, F. (2001), Two Mezzogiornos, in M. Bordignon and D. da Empoli (eds.), Politica fiscale, flessibilità dei mercati e crescita, Milano: Franco Angeli. 
Snower, D.J. (1996), The Low-Skill, Bad-Job Trap, in A.L. Booth and D.J. Snower (eds.), Acquiring Skills, Cambridge: Cambridge University Press.

Solow, R. (1956), A Contribution to the Theory of Economic Growth, Quaterly Journal of Economics 70, 65-94.

Soskice, D. (1990), Wage Determination: The Changing Role of Institutions in Advanced Industrialized Countries, Oxford Review of Economic Policy 6, No. $4,36-61$. 
Elenco dei papers del Dipartimento di Economia

1989. 1. Knowledge and Prediction of Economic Behaviour: Towards A Constructivist Approach. by Roberto Tamborini.

1989. 2. Export Stabilization and Optimal Currency Baskets: the Case of Latin AmericanCountries. by Renzo G.Avesani Giampiero M. Gallo and Peter Pauly.

1989. 3. Quali garanzie per i sottoscrittori di titoli di Stato? Una rilettura del rapporto della Commissione Economica dell'Assemblea Costituente di Franco Spinelli e Danilo Vismara.

(What Guarantees to the Treasury Bill Holders? The Report of the Assemblea Costituente Economic Commission Reconsidered by Franco Spinelli and Danilo Vismara.)

1989. 4. L'intervento pubblico nell'economia della "Venezia Tridentina" durante l'immediato dopoguerra di Angelo Moioli.

(The Public Intervention in "Venezia Tridentina" Economy in the First War Aftermath by Angelo Moioli.)

1989. 5. L'economia lombarda verso la maturità dell'equilibrio agricolo-commerciale durante l'età delle riforme di Angelo Moioli.

(The Lombard Economy Towards the Agriculture-Trade Equilibrium in the Reform Age by Angelo Moioli.)

1989. 6. L'identificazione delle allocazioni dei fattori produttivi con il duale. di Quirino Paris e di Luciano Pilati.

(Identification of Factor Allocations Through the Dual Approach by Quirino Paris and Luciano Pilati.)

1990. 1. Le scelte organizzative e localizzative dell'amministrazione postale: un modello intrpretativo.di Gianfranco Cerea. 
(The Post Service' sOrganizational and Locational Choices: An Interpretative Model by Gianfranco Cerea.)

1990. 2. Towards a Consistent Characterization of the Financial Economy. by Roberto Tamborini.

1990. 3. Nuova macroeconomia classica ed equilibrio economico generale: considerazioni sulla pretesa matrice walrasiana della N.M.C. di Giuseppe Chirichiello.

(New Classical Macroeconomics and General Equilibrium: Some Notes on the Alleged Walrasian Matrix of the N.C.M.by Giuseppe Chirichiello.)

1990. 4. Exchange Rate Changes and Price Determination in Polypolistic Markets. by Roberto Tamborini.

1990. 5. Congestione urbana e politiche del traffico. Un' analisi economica di Giuseppe Folloni e Gianluigi Gorla.

(Urban Congestion and Traffic Policy. An Economic Analysis by Giuseppe Folloni and Gianluigi Gorla.)

1990. 6. Il ruolo della qualità nella domanda di servizi pubblici. Un metodo di analisi empirica di Luigi Mittone.

(The Role of Quality in the Demand for Public Services. A Methodology for Empirical Analysis by Luigi Mittone.)

1991. 1. Consumer Behaviour under Conditions of Incomplete Information on Quality: a Note by Pilati Luciano and Giuseppe Ricci.

1991. 2. Current Account and Budget Deficit in an Interdependent World by Luigi Bosco.

1991. 3. Scelte di consumo, qualità incerta e razionalità limitata di Luigi Mittone e Roberto Tamborini. 
(Consumer Choice, Unknown Quality and Bounded Rationality by Luigi Mittone and Roberto Tamborini.)

1991. 4. Jumping in the Band: Undeclared Intervention Thresholds in a Target Zone by Renzo G. Avesani and Giampiero M. Gallo.

1991. 5 The World Tranfer Problem. Capital Flows and the Adjustment of Payments by Roberto Tamborini.

1992.1 Can People Learn Rational Expectations? An Ecological Approach by Pier Luigi Sacco.

1992.2 On Cash Dividends as a Social Institution by Luca Beltrametti.

1992.3 Politica tariffaria e politica informativa nell' offerta di servizi pubblici di Luigi Mittone

(Pricing and Information Policy in the Supply of Public Services by Luigi Mittone.)

1992.4 Technological Change, Technological Systems, Factors of Production by Gilberto Antonelli and Giovanni Pegoretti.

1992.5 Note in tema di progresso tecnico di Geremia Gios e Claudio Miglierina.

(Notes on Technical Progress, by Geremia Gios and Claudio Miglierina).

1992.6 Deflation in Input Output Tables by Giuseppe Folloni and Claudio Miglierina.

1992.7 Riduzione della complessità decisionale: politiche normative e produzione di informazione di Luigi Mittone

(Reduction in decision complexity: normative policies and information production by Luigi Mittone) 
1992.8 Single Market Emu and Widening. Responses to Three Institutional Shocks in the European Community by Pier Carlo Padoan and Marcello Pericoli

1993.1 La tutela dei soggetti "privi di mezzi": Criteri e procedure per la valutazione della condizione economica di Gianfranco Cerea

(Public policies for the poor: criteria and procedures for a novel means test by Gianfranco Cerea )

1993.2 La tutela dei soggetti "privi di mezzi": un modello matematico per la rappresentazione della condizione economica di Wolfgang J. Irler

(Public policies for the poor: a mathematical model for a novel means test by Wolfgang J.Irler)

1993.3 Quasi-markets and Uncertainty: the Case of General Proctice Service by Luigi Mittone

1993.4 Aggregation of Individual Demand Functions and Convergence to Walrasian Equilibria by Dario Paternoster

1993.5 A Learning Experiment with Classifier System: the Determinants of the Dollar-Mark Exchange Rate by Luca Beltrametti, Luigi Marengo and Roberto Tamborini

1993.6 Alcune considerazioni sui paesi a sviluppo recente di Silvio Goglio

(Latecomer Countries: Evidence and Comments by Silvio Goglio)

1993.7 Italia ed Europa: note sulla crisi dello SME di Luigi Bosco

( Italy and Europe: Notes on the Crisis of the EMS by Luigi Bosco) 
1993.8 Un contributo all' analisi del mutamento strutturale nei modelli input-output di Gabriella Berloffa

(Measuring Structural Change in Input-Output Models: a Contribution by Gabriella Berloffa)

1993.9 On Competing Theories of Economic Growth: a Crosscountry Evidence by Maurizio Pugno

1993.10 Le obbligazioni comunali di Carlo Buratti (Municipal Bonds by Carlo Buratti)

1993.11 Due saggi sull' organizzazione e il finanziamento della scuola statale di Carlo Buratti

(Two Essays on the Organization and Financing of Italian State Schools by Carlo Buratti

1994.1 Un' interpretazione della crescita regionalelleaders, attività indotte e conseguenze di policy di Giuseppe Folloni e Silvio Giove.

(A Hypothesis about regional Growth: Leaders, induced Activities and Policy by Giuseppe Folloni and Silvio Giove).

1994.2 Tax evasion and moral constraints: some experimental evidence by Luigi Bosco and Luigi Mittone.

1995.1 A Kaldorian Model of Economic Growth with Shortage of Labour and Innovations by Maurizio Pugno.

1995.2 A che punto è la storia d'impresa? Una riflessione storiografica e due ricerche sul campo a cura di Luigi Trezzi.

1995.3 Il futuro dell' impresa cooperativa: tra sistemi, reti ed ibridazioni di Luciano Pilati.

(The future of the cooperative enterprise: among systems, networks and hybridisation by Luciano Pilati). 
1995.4 Sulla possibile indeterminatezza di un sistema pensionistico in perfetto equilibrio finanziario di Luca Beltrametti e Luigi Bonatti.

(On the indeterminacy of a perfectly balanced social security system by Luca Beltrametti and Luigi Bonatti).

1995.5 Two Goodwinian Models of Economic Growth for East Asian NICs by Maurizio Pugno.

1995.6 Increasing Returns and Externalities: Introducing Spatial Diffusion into Krugman' sEconomic Geography by Giuseppe Folloni and Gianluigi Gorla.

1995.7 Benefit of Economic Policy Cooperation in a Model with Current Account Dynamics and Budget Deficit by Luigi Bosco.

1995.8 Coalition and Cooperation in Interdependent Economies by Luigi Bosco.

1995.9 La finanza pubblica italiana e l'ingresso nell' unione monetaria europea di Ferdinando Targetti.

(Italian Public Finance and the Entry in the EMU by Ferdinando Targetti)

1996.1 Employment, Growth and Income Inequality: some open Questions by Annamaria Simonazzi and Paola Villa.

1996.2 Keynes' Idea of Uncertainty: a Proposal for its Quantification by Guido Fioretti.

1996.3 The Persistence of a "Low-Skill, Bad-Job Trap" in a Dynamic Model of a Dual Labor Market by Luigi Bonatti.

1996.4 Lebanon: from Development to Civil War by Silvio Goglio. 
1996.5 A Mediterranean Perspective on the Break-Down of the Relationship between Participation and Fertility by Francesca Bettio and Paola Villa.

1996.6 Is there any persistence in innovative activities? by Elena Cefis.

1997.1 Imprenditorialità nelle alpi fra età moderna $e$ contemporanea a cura di Luigi Trezzi.

1997.2 Il costo del denaro è uno strumento anti-inflazionistico? di Roberto Tamborini.

(Is the Interest Rate an Anti-Inflationary Tool? by Roberto Tamborini).

1997.3 A Stability Pact for the EMU? by Roberto Tamborini.

1997.4 Mr Keynes and the Moderns by Axel Leijonhufvud.

1997.5 The Wicksellian Heritage by Axel Leijonhufvud.

1997.6 On pension policies in open economies by Luca Beltrametti and Luigi Bonatti.

1997.7 The Multi-Stakeholders Versus the Nonprofit Organisation by Carlo Borzaga and Luigi Mittone.

1997.8 How can the Choice of a Tme-Consistent Monetary Policy have Systematic Real Effects? by Luigi Bonatti.

1997.9 Negative Externalities as the Cause of Growth in a Neoclassical Model by Stefano Bartolini and Luigi Bonatti. 
1997.10 Externalities and Growth in an Evolutionary Game by Angelo Antoci and Stefano Bartolini.

1997.11 An Investigation into the New Keynesian

Macroeconomics of Imperfect Capital Markets by Roberto Tamborini.

1998.1 Assessing Accuracy in Transition Probability Matrices by Elena Cefis and Giuseppe Espa.

1998.2 Microfoundations: Adaptative or Optimizing? by Axel Leijonhufvud.

1998.3 Clower's intellectual voyage: the 'Ariadne's thread' of continuity through changes by Elisabetta De Antoni.

1998.4 The Persistence of Innovative Activities. A Cross-Countries and Cross-Sectors Comparative Analysis by Elena Cefis and Luigi Orsenigo

1998.5 Growth as a Coordination Failure by Stefano Bartolini and Luigi Bonatti

1998.6 Monetary Theory and Central Banking by Axel Leijonhufvud

1998.7 Monetary policy, credit and aggregate supply: the evidence from Italy by Riccardo Fiorentini and Roberto Tamborini

1998.8 Stability and multiple equilibria in a model of talent, rent seeking, and growth by Maurizio Pugno

1998.9 Two types of crisis by Axel Leijonhufvud 
1998.10 Trade and labour markets: vertical and regional differentiation in Italy by Giuseppe Celi e Maria Luigia Segnana

1998.11 Utilizzo della rete neurale nella costruzione di un trading system by Giulio Pettenuzzo

1998.12 The impact of social security tax on the size of the informal economy by Luigi Bonatti

1999.1 L'economia della montagna interna italiana: un approccio storiografico, a cura di Andrea Leonardi e Andrea Bonoldi.

1999.2 Unemployment risk, labour force participation and savings, by Gabriella Berloffa e Peter Simmons

1999.3 Economia sommersa, disoccupazione e crescita, by Maurizio Pugno

1999.4 The nationalisation of the British Railways in Uruguay, by Giorgio Fodor

1999.5 Elements for the history of the standard commodity, by Giorgio Fodor

1999.6 Financial Market Imperfections, Heterogeneity and growth, by Edoardo Gaffeo

1999.7 Growth, real interest, employment and wage determination, by Luigi Bonatti

2000.1 A two-sector model of the effects of wage compression on unemployment and industry distribution of employment, by Luigi Bonatti 
2000.2 From Kuwait to Kosovo: What have we learned? Reflections on globalization and peace, by Roberto Tamborini

2000.3 Metodo e valutazione in economia. Dall'apriorismo a Friedman, by Matteo Motterlini

2000.4 Under tertiarisation and unemployment. by Maurizio Pugno

2001.1 Growth and Monetary Rules in a Model with Competitive Labor Markets, by Luigi Bonatti.

2001.2 Profit Versus Non-Profit Firms in the Service Sector: an Analysis of the Employment and Welfare Implications, by Luigi Bonatti, Carlo Borzaga and Luigi Mittone.

2001.3 Statistical Economic Approach to Mixed Stock-Flows Dynamic Models in Macroeconomics, by Bernardo Maggi and Giuseppe Espa.

2001.4 The monetary transmission mechanism in Italy: The credit channel and a missing ring, by Riccardo Fiorentini and Roberto Tamborini.

2001.5 Vat evasion: an experimental approach, by Luigi Mittone

2001.6 Decomposability and Modularity of Economic Interactions, by Luigi Marengo, Corrado Pasquali and Marco Valente.

2001.7 Unbalanced Growth and Women's Homework, by Maurizio Pugno

2002.1 The Underground Economy and the Underdevelopment Trap, by Maria Rosarua Carillo and Maurizio Pugno 
2002.2 Interregional Income Redistribution and Convergence in a Model with Perfect Capital Mobility and Unionized Labor Markets, by Luigi Bonatti 
PUBBLICAZIONE REGISTRATA PRESSO IL TRIBUNALE DI TRENTO 67 
